\title{
Tropical Pacific Climate and Its Response to Global Warming in the Kiel Climate Model
}

\author{
W. Park, N. Keenlyside, M. Latif, And A. Ströh \\ Leibniz-Institut für Meereswissenschaften, Kiel, Germany \\ R. REDLER \\ NEC Laboratories Europe, NEC Europe Ltd., Sankt Augustin, Germany \\ E. ROECKNER \\ Max-Planck-Institut für Meteorologie, Hamburg, Germany \\ G. MADEC \\ LOCEAN, Institut Pierre Simon Laplace, Paris, France
}

(Manuscript received 1 October 2007, in final form 18 May 2008)

\begin{abstract}
A new, non-flux-corrected, global climate model is introduced, the Kiel Climate Model (KCM), which will be used to study internal climate variability from interannual to millennial time scales and climate predictability of the first and second kind. The version described here is a coarse-resolution version that will be employed in extended-range integrations of several millennia. KCM's performance in the tropical Pacific with respect to mean state, annual cycle, and El Niño-Southern Oscillation (ENSO) is described. Additionally, the tropical Pacific response to global warming is studied.

Overall, climate drift in a multicentury control integration is small. However, KCM exhibits an equatorial cold bias at the surface of the order $1^{\circ} \mathrm{C}$, while strong warm biases of several degrees are simulated in the eastern tropical Pacific on both sides off the equator, with maxima near the coasts. The annual and semiannual cycles are realistically simulated in the eastern and western equatorial Pacific, respectively. ENSO performance compares favorably to observations with respect to both amplitude and period.

An ensemble of eight greenhouse warming simulations was performed, in which the $\mathrm{CO}_{2}$ concentration was increased by $1 \% \mathrm{yr}^{-1}$ until doubling was reached, and stabilized thereafter. Warming of equatorial Pacific sea surface temperature (SST) is, to first order, zonally symmetric and leads to a sharpening of the thermocline. ENSO variability increases because of global warming: during the 30 -yr period after $\mathrm{CO}_{2}$ doubling, the ensemble mean standard deviation of Niño-3 SST anomalies is increased by $26 \%$ relative to the control, and power in the ENSO band is almost doubled. The increased variability is due to both a strengthened (22\%) thermocline feedback and an enhanced (52\%) atmospheric sensitivity to SST; both are associated with changes in the basic state. Although variability increases in the mean, there is a large spread among ensemble members and hence a finite probability that in the "model world" no change in ENSO would be observed.
\end{abstract}

\section{Introduction}

Coupled air-sea feedbacks in the tropical Pacific influence its annual mean state, annual cycle, and interannual variability. For instance, the existence of an an-

Corresponding author address: Dr. Wonsun Park, Leibniz Institute of Marine Sciences (IFM-GEOMAR), Duesternbrooker Weg 20, D-24105 Kiel, Germany.

E-mail:wpark@ifm-geomar.de nual cycle in the eastern equatorial Pacific, which is unexpected since the sun crosses the equator twice, is due to such coupled interactions. Also, the El NiñoSouthern Oscillation (ENSO) phenomenon, the most pronounced interannual climate fluctuation, is an inherently coupled air-sea mode. Furthermore, ENSO derives its predictability potential from its coupled nature.

The simulation of tropical Pacific climate and its variability, however, has proven a challenge for global cli- 
mate models (e.g., Neelin et al. 1992; Latif et al. 1994; Achuta Rao and Sperber 2000; Latif et al. 2001; van Oldenborgh et al. 2005; Achuta Rao and Sperber 2006; Guilyardi et al. 2004; Lin 2007). This is partly due to the presence of unstable air-sea interactions, which tend to amplify biases in the individual model components. An important one is the Bjerknes feedback (Bjerknes 1969; Neelin et al. 1998), which is a positive feedback between the zonal wind stress, thermocline depth, and SST at the equator. Another example is the cloud cover-SST feedback (Ma et al. 1996; Philander et al. 1996) in the eastern off-equatorial oceans.

Apart from the feedbacks there are several other difficulties in simulating tropical Pacific climate. The following is not an exhaustive list but includes ones that we believe to be important. Resolution matters and is often a limiting factor for a realistic simulation in both the ocean and the atmosphere. The simulation of internal ocean waves (Busalacchi and O'Brien 1981), which play an important role in ENSO dynamics (Schopf and Suarez 1988), and the narrow equatorial and coastal upwelling zones require relatively high horizontal resolution in the ocean that is often not affordable in global climate models. Likewise, the steep orography associated with the Andes affecting the local wind regimes that drive upwelling in the ocean can be adequately resolved only using relatively high-resolution in the atmosphere. Finally, most global climate models do not resolve the tropical instability waves, which contribute to the ocean heat transport toward the equator, as described by Jochum et al. (2005). Resolving tropical instability waves may help to reduce the so-called cold bias problem in the equatorial Pacific, one of the most important problems in coupled ocean-atmosphere models (Neelin et al. 1992; Latif et al. 2001).

In addition to being challenging, the tropical Pacific is a welcome test bed for global climate models and the employed physical parameterizations for several reasons. For example, first, because coupled feedbacks are important; second, because the internal time scales are small, so that only relatively short integrations are required; and third, because an observing system is in place, the Tropical Ocean and Global Atmosphere Tropical Atmosphere-Ocean (TOGA TAO) array (McPhaden et al. 1990), which enables quantitative model/data comparisons. Finally, because the socioeconomic impacts of tropical Pacific variability, particularly ENSO, are large, requiring realistic simulation of not only first but also higher statistical moments. There is a wide range of model behavior in the tropical Pacific that is reflected in both climatology and variability. This applies also to the response of the tropical Pacific to global warming (see, e.g., the recent studies by van Oldenborgh et al. 2005 and Guilyardi 2006). Even the change of the mean state in response to global warming is not the same in all models. The Cane and Zebiak model (Zebiak and Cane 1987), for instance, simulates a "La Niña-like" response, while most other models simulate an "El Niño-like" change (Collins et al. 2005). Some models show a weakening of the interannual variability, other models simulate an increase, and again other models yield virtually no change. Theoretical studies show that the mean state has a strong influence on ENSO statistics (Battisti and Hirst 1989), so that model biases may determine the nature of the interannual variability and thus its response to global warming (Fedorov and Philander 2000). Likewise, the decadal variability of the subtropical cells (STCs) is not well captured by some climate models (Solomon and Zhang 2006) and their response to global warming is highly uncertain, varying strongly from model to model, even with respect to sign (K. Lohmann 2006, personal communication).

Here we describe the first version of the Kiel Climate Model (KCM), a coupled ocean-atmosphere-sea ice model that will serve as the dynamical core of the earth system model being developed at the Leibniz Institute of Marine Sciences. The model is effectively the next generation of the scale interactions experiments (SINTEX) family (Gualdi et al. 2003; Guilyardi et al. 2003; Luo et al. 2005) of models, as each component has been updated to the most recent version. This is the first paper describing KCM, and results using a relatively coarse model resolution are presented, with a focus on the tropical Pacific. We compare KCM's performance to observations and contribute also to the discussion on the tropical Pacific response to global warming. Forthcoming papers will deal with lowerfrequency climate variations, specifically the multidecadal variations of the Atlantic meridional overturning circulation (MOC) and including its interaction with ENSO, and with the extension of KCM by adding other components of the earth system. Special emphasis will be put on the coupling of ocean biogeochemistry and the investigation of the coupled physical-ocean biogeochemistry response to global warming.

This paper is organized as follows: we describe the model and the experiments in section 2. The mean state and the annual cycle simulated by KCM are compared to observations in section 3. ENSO performance is discussed in section 4, while the tropical Pacific response to global warming is described in section 5. We conclude the paper with a brief summary and a discussion of our main findings in section 6 . 


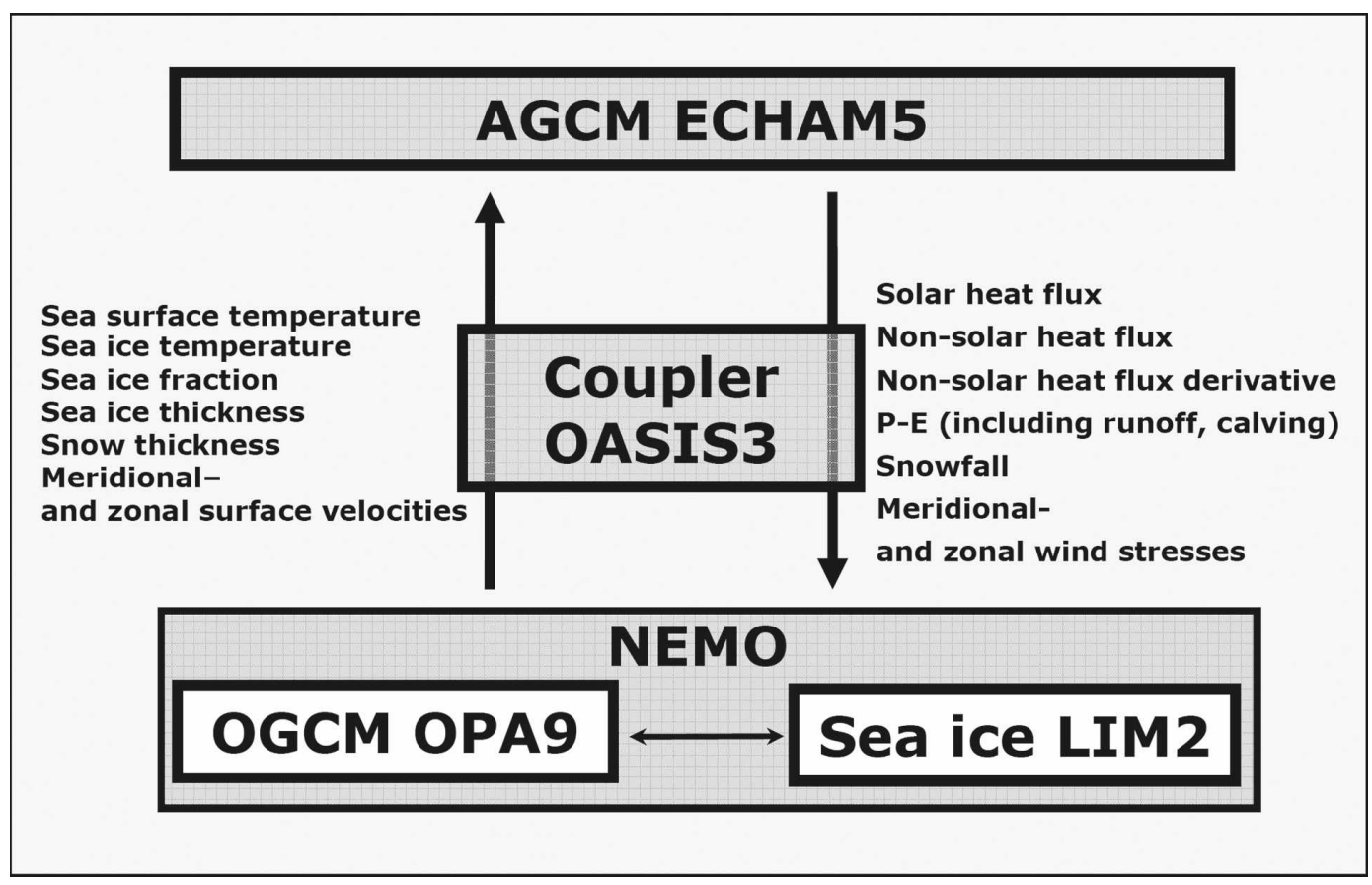

FIG. 1. Schematic of the KCM.

\section{Model and experiments}

KCM consists of the European Centre for MediumRange Weather Forecasts (ECMWF) Hamburg atmospheric general circulation model version 5 (ECHAM5; Roeckner et al. 2003) atmospheric general circulation model (AGCM) coupled to the Nucleus for European Modeling of the Ocean (NEMO; Madec et al. 1998; Madec 2008) ocean-sea ice general circulation model, with the Ocean Atmosphere Sea Ice Soil version 3 (OASIS3; Valcke 2006) coupler. No form of flux correction or anomaly coupling, either in freshwater, heat, or wind stress is used. A brief description of the model components and the experiments performed is now given; a schematic overview of the model is shown in Fig. 1.

ECHAM5 is the latest version of the ECHAM model developed at the Max Planck Institute for Meteorology (MPI). It is a spectral model employing state-of-the-art physics. A detailed description of the model is given in Roeckner et al. (2003); a more concise summary of the model can be found in Roeckner et al. (2006), where the sensitivity of results to resolution is described. The model (as part of the MPI climate model) was used to carry out scenario simulations for the Intergovernmental Panel on Climate Change (IPCC) 2007 fourth assessment report (AR4; Solomon et al. 2007). However, in contrast to the ECHAM5 model version used by MPI in the IPCC AR4, we use the model's statistical cloud cover scheme (Tompkins 2002). In this scheme fractional cloudiness is calculated statistically, using a probability density function for total water, as suggested from high-resolution cloud-resolving model simulations of tropical deep convection.

NEMO (Madec et al. 1998; Madec 2008) consists of the Océan Parallélisé version 9 (OPA9) ocean general circulation model (OGCM) and the Louvain-la-Neuve Ice Model version 2 (LIM2) sea ice model. OPA9 is the most recent version of the OPA model developed at the Laboratory of Oceanography and Climatology (LOCEAN), Institut Pierre Simon Laplace (IPSL). OPA is widely applied in oceanography (research and operational) and climate change studies. It is a $z$ coordinate OGCM that includes the most recent developments in ocean modeling, such as partial bottom cells and a free surface formulation. Details on most aspects of the model can be found in Madec (2008). Details on sensitivity of the solution to partial cells and advections schemes is given by Barnier et al. (2006), who also provide a concise summary of the model physics. LIM is a 3-level dynamic-thermodynamic sea ice-snow model developed at Louvaine-la-Neuve (Fichefet and Morales Maqueda 1997). Previous versions of both OPA and LIM, as part of global coupled models [Istituto Nazionale di Geofisica e Vulcanologia (INGV), IPSL], have contributed to the IPCC AR4 (Solomon et al. 2007).

The coupling strategy in $\mathrm{KCM}$ is as follows: NEMO 
receives surface heat flux, freshwater flux, and wind stress from ECHAM5 via OASIS3 coupler through a new technical interface that was coded during the development of KCM and implemented in NEMO. The heat flux is separated into a solar and nonsolar part, and calculated separately over water and sea ice. In addition and for the sake of the numerical stability of the sea ice model, the derivative of nonsolar heat flux with respect to surface temperature is passed. Net freshwater flux (precipitation minus evaporation) includes river runoff and glacier calving, both of which are provided by ECHAM5's hydrological model. Snowfall is passed additionally to be used for the sea ice model. Sea surface temperature, surface ocean velocity, sea ice fraction, sea ice temperature, sea ice thickness, and snow thickness are transferred from NEMO to the ECHAM5 atmosphere model via the coupler. These physical fields are used for calculation of heat, freshwater, and momentum fluxes in the atmosphere. Sea ice dynamics and thermodynamics are calculated inside of the sea ice model every five ocean time steps. The coupling frequency between the ocean and atmosphere is once per day. In the KCM simulations described here, the atmospheric resolution is $\mathrm{T} 31\left(3.75^{\circ} \times 3.75^{\circ}\right)$ horizontally with 19 vertical levels. The horizontal ocean resolution is based on a $2^{\circ}$ Mercator mesh and is on average $1.3^{\circ}$, with enhanced meridional resolution of $0.5^{\circ}$ close to the equator (ORCA2 grid), and with 31 levels in the vertical. The OASIS3 coupler interpolates the exchange fields described above to and from source and target model grids.

Here we analyze two experiments: a twentiethcentury equivalent (20C) control experiment that assumes "present day" values for greenhouse gases $\left(\mathrm{CO}_{2}=348 \mathrm{ppm}\right)$ and a series of eight 100-yr-long global warming simulations [twenty-first-century equivalent $(21 \mathrm{C})]$. In the latter, $\mathrm{CO}_{2}$ concentration is increased at $1 \% \mathrm{yr}^{-1}$ (compound) till $\mathrm{CO}_{2}$ doubling is reached, after about $70 \mathrm{yr}$, and stabilized thereafter for another $30 \mathrm{yr}$. The $20 \mathrm{C}$ control simulation is $430 \mathrm{yr}$ long, but only the last $330 \mathrm{yr}$ are analyzed here. The initial conditions are taken from a long $(500 \mathrm{yr})$ coupled model simulation, with different parameter values. This spinup run started from the Levitus et al. (1998) climatology. The $21 \mathrm{C}$ global warming experiments were started from initial conditions chosen semiregularly with 30 - or $40-\mathrm{yr}$ intervals from the $20 \mathrm{C}$ control run (Fig. 2).

\section{Climatology}

The model climate is relatively stable, as illustrated by the simulated globally averaged 2-m air temperature [surface air temperature (SAT); Fig. 2]. The global

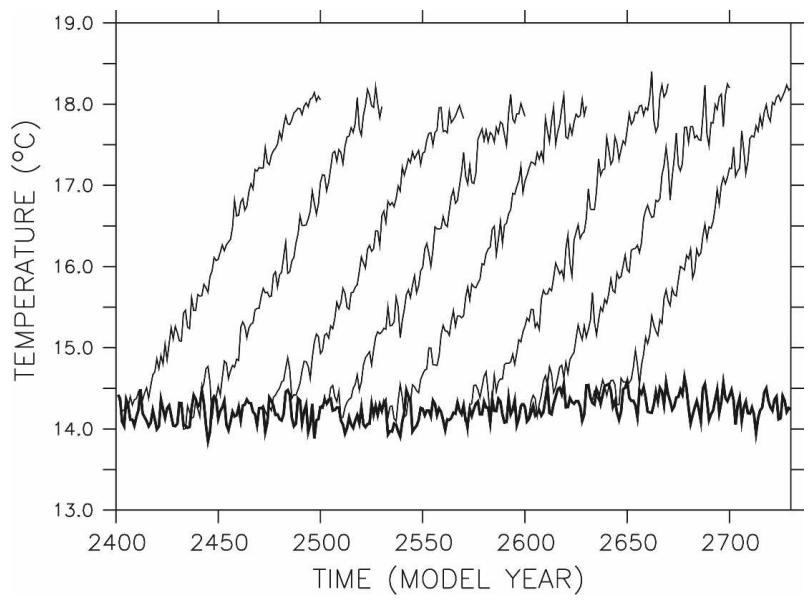

FIG. 2. Global mean 2-m air temperatures $\left({ }^{\circ} \mathrm{C}\right)$ of control $(20 \mathrm{C}$, thick line) and 8 members of global warming experiments $(21 \mathrm{C}$, thin line) started from different initial conditions. In the $21 \mathrm{C} \mathrm{ex}$ periments, $\mathrm{CO}_{2}$ concentration is increased at $1 \% \mathrm{yr}^{-1}$ until doubling and then stabilized.

mean temperature averaged over the length of the simulation equals $14.24^{\circ} \pm 0.15^{\circ} \mathrm{C}$, which compares well with the observed surface air temperature mean over the period $1971-2004$ of $13.91^{\circ} \pm 0.20^{\circ} \mathrm{C}$ from National Centers for Environmental Prediction-National Center for Atmospheric Research (NCEP-NCAR) reanalysis (Kalnay et al. 1996). The mean SST bias pattern calculated from last $100 \mathrm{yr}$ of the control experiment (Fig. 3) compares favorably to those simulated by other stateof-the-art coupled global climate models (CGCMs; Latif et al. 2001), particularly given the low resolution in the atmosphere. A common problem is seen in the North Atlantic, where SSTs are up to $9^{\circ} \mathrm{C}$ too cold. This bias is most likely due to a too southward flowing and diffusive North Atlantic Current, but may also be due to deficiencies in the atmosphere such as in the stormtrack position. In the tropics biases are generally not greater than $1^{\circ} \mathrm{C}$, except for the warm biases along the east coast of South America, North America, and Africa. The latter biases are common to many CGCMs, and are partly due to the incorrect representation of stratocumulus clouds and coastal upwelling, as was inferred from uncoupled integrations with the respective model components. The problem is particularly acute in the tropical Atlantic where, as in most other models (Davey et al. 2002), the warm bias extends across most of the basin and reverses the zonal SST gradient along the equator.

In the tropical Pacific, the area of focus for the remainder of the paper, the SST biases are smaller than in many state-of-the-art CGCMs (Guilyardi 2006): SSTs in the equatorial cold tongue are about $1^{\circ} \mathrm{C}$ too low 


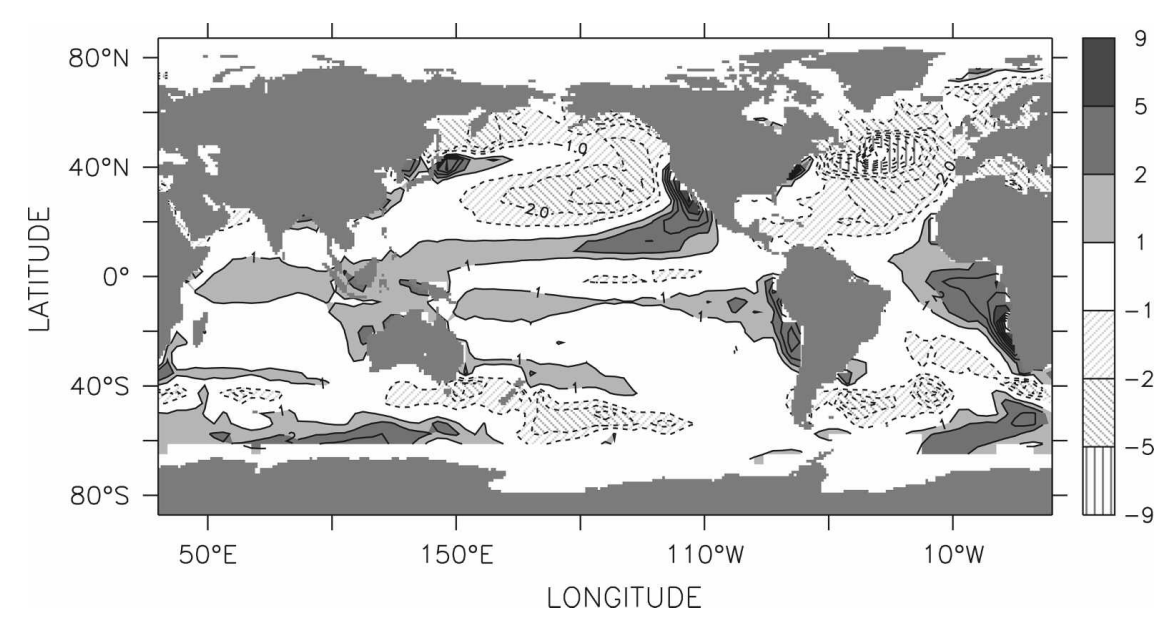

FIG. 3. SST bias $\left({ }^{\circ} \mathrm{C}\right)$ of $20 \mathrm{C}$ control simulation averaged over last $100 \mathrm{yr}$ referenced to observation (Reynolds and Smith 1994; CI $=0.1^{\circ} \mathrm{C}$ ).

(Fig. 3); averaged over the Niño-3 region $\left(5^{\circ} \mathrm{S}-5^{\circ} \mathrm{N}\right.$, $150^{\circ}-90^{\circ} \mathrm{W}$ ) simulated SST equals $25.22^{\circ} \mathrm{C}$, while the observed value is $25.69^{\circ} \mathrm{C}$ [1870-2004; Hadley Centre Sea Ice and Sea Surface Temperature dataset (HadISST); Rayner et al. 2003]. The equatorial cold bias is associated with too strong surface zonal wind stress (Figs. 4a,b), as compared to the NCEP-NCAR reanalysis (Kalnay et al. 1996); averaged over the Niño-4 region $\left(5^{\circ} \mathrm{S}-5^{\circ} \mathrm{N}, 160^{\circ} \mathrm{E}-150^{\circ} \mathrm{W}\right)$ simulated zonal wind stress is $-0.052 \mathrm{~Pa}$, which is larger than that of many models (Guilyardi 2006) and the NCEP-NCAR reanalysis $(-0.029 \mathrm{~Pa})$. Maximum wind stress curl is located more northward than in observations, and the strength is enhanced in the model (Figs. 4c,d). KCM produces more precipitation than observed (Xie and Arkin 1997) in the convergence zones and the rainfall maxima are shifted somewhat poleward (Figs. 4e,f). The South Pacific convergence zone (SPCZ), which is oriented in a northwest-southeast direction in observations, is more zonally orientated in the model and extends too far east. Nevertheless the model produces a reasonable overall distribution. The equatorial thermocline (Fig. 5a) is well simulated: The east-west slope is only slightly stronger than in observations (Fig. 5b), which results from the overly strong equatorial surface zonal wind stress. Common to many ocean models, the simulated thermocline is too diffusive. The simulated $20^{\circ} \mathrm{C}$ isotherm depth $\left(Z_{20}\right)$ along the equator is comparable to the observations, while it is shallower than observed in the subtropics (Figs. 5c,d).

The model simulates both tropical and subtropical cells (Fig. 5e) that agree with results from a forced simulation (Fig. 5f) of the ocean component of the coupled model, NEMO, driven with Common OceanIce Reference Experiments (CORE; Large and Yeager
2004) forcing. The meridional (zonally integrated) upper-ocean circulation is expressed by the overturning streamfunction $\Psi$. The subtropical cell strengths of the coupled and uncoupled runs are very similar in the south, while the northern circulation is approximately $30 \%$ stronger in the coupled model simulation. The latter difference is due to stronger surface wind stress (curl) in the coupled model, as described above.

The simulated annual cycle in the eastern Pacific along the equator, shown as deviation from the annual mean (Fig. 6a), agrees quite well with observations (Rayner et al. 2003) (Fig. 6b) in terms of strength and westward phase propagation; this is not the case in many other models (Latif et al. 2001). In terms of phase, the simulated annual cycle in the east lags the observed one by a month: SSTs are warmest (coldest) in April (September-October) in KCM as compared to March (August-September) in observations. In the western and parts of the central equatorial Pacific, the model correctly captures the observed semiannual cycle in terms of phase. The simulated semiannual cycle is, however, mostly overestimated: the model SST near the date line, for instance, varies by more than $\pm 0.5^{\circ} \mathrm{C}$, whereas the observed variations are much smaller and attain appreciable magnitude only in a rather small region in the very western Pacific, where in turn the model variability is much too weak.

\section{ENSO variability}

In the previous section, it was shown that KCM realistically simulates important aspects of the mean tropical Pacific climate and the annual cycle, both of which are believed to be important for ENSO. In accord with this, the model simulates tropical Pacific SST 
(a) Zonal wind stress $\left(10^{-2} \mathrm{~Pa}\right), 20 \mathrm{C}$

(b) NCEP (1950-2004)

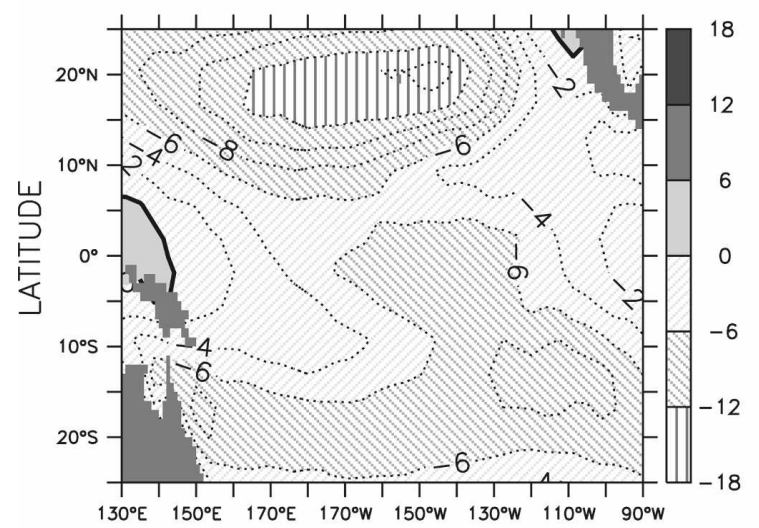

LONGITUDE

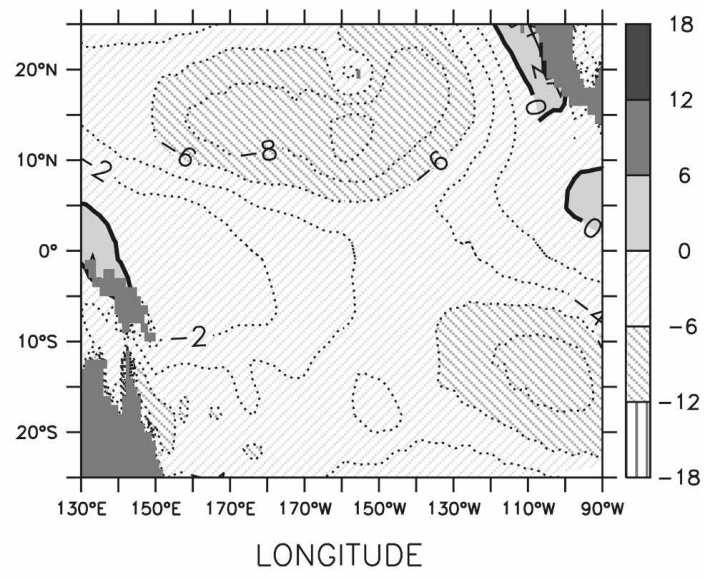

(c) Wind stress curl $\left(10^{-8} \mathrm{Nm}^{-3}\right), 20 \mathrm{C}$

(d) NCEP (1950-2004)

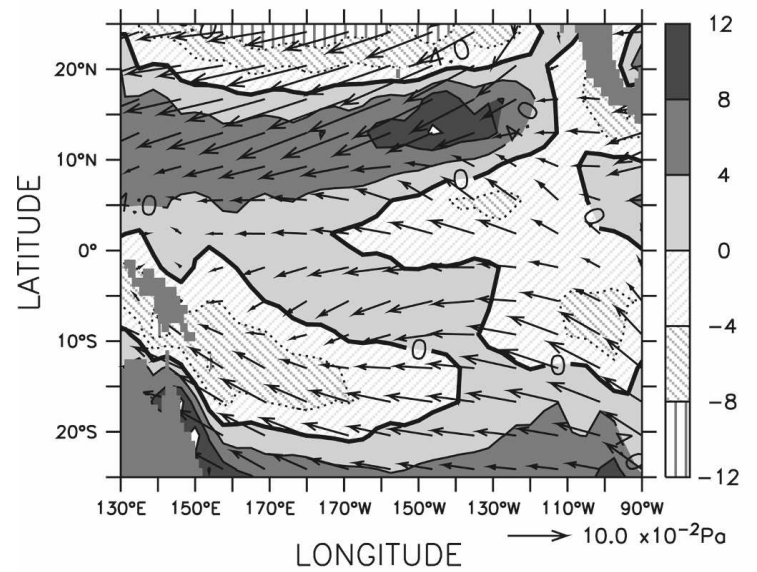

(e) Precipitation ( $\mathrm{mm} /$ day), $20 \mathrm{C}$

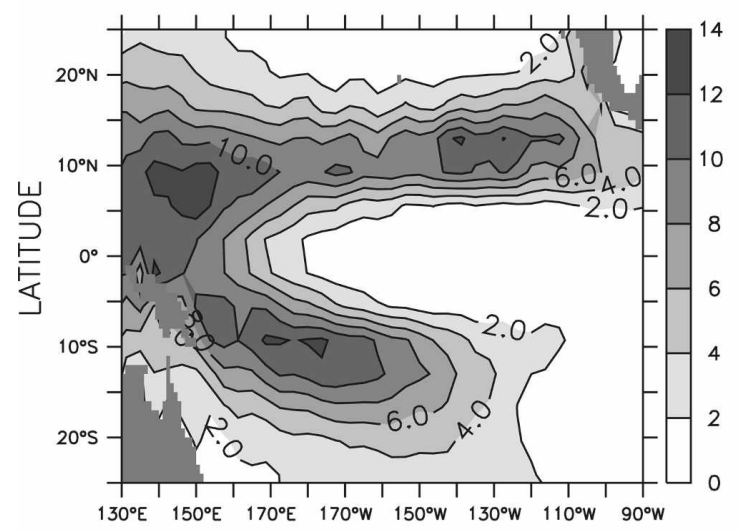

LONGITUDE

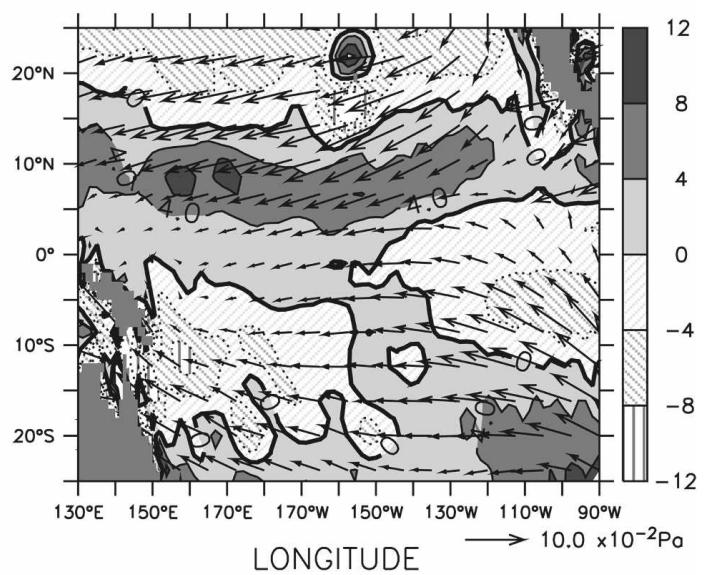

(f) Xie and Arkin (1979-2002)

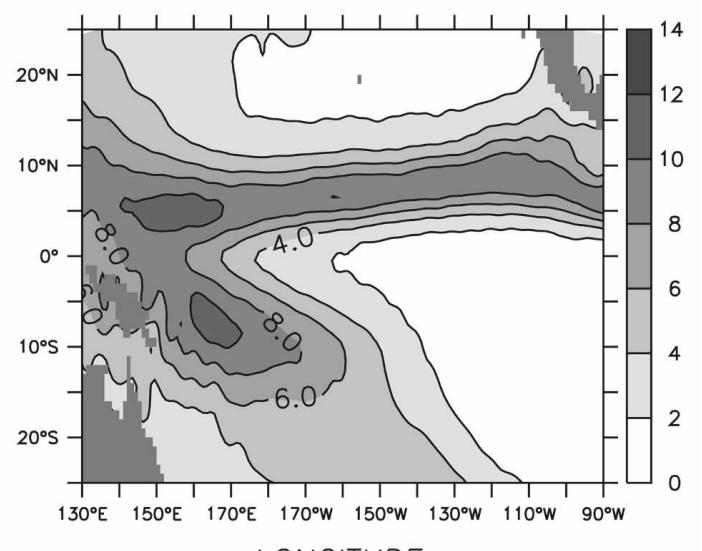

LONGITUDE

FIG. 4. Annual mean of (a)-(b) eastward zonal wind stress $\left(10^{-2} \mathrm{~Pa}\right)(\mathrm{CI}=0.02 \mathrm{~Pa}),(\mathrm{c})-(\mathrm{d})$ wind stress $($ arrow $)\left(10^{-1}\right.$ $\mathrm{Pa}$ ) and its curl $\left(10^{-8} \mathrm{~N} \mathrm{~m}^{-3}\right)$, and (e)-(f) precipitation $\left(\mathrm{mm} \mathrm{day}^{-1}\right)$ of the (left) 20C control simulation and (right) observations. 
(a) Temperature $\left({ }^{\circ} \mathrm{C}\right), 20 \mathrm{C}$

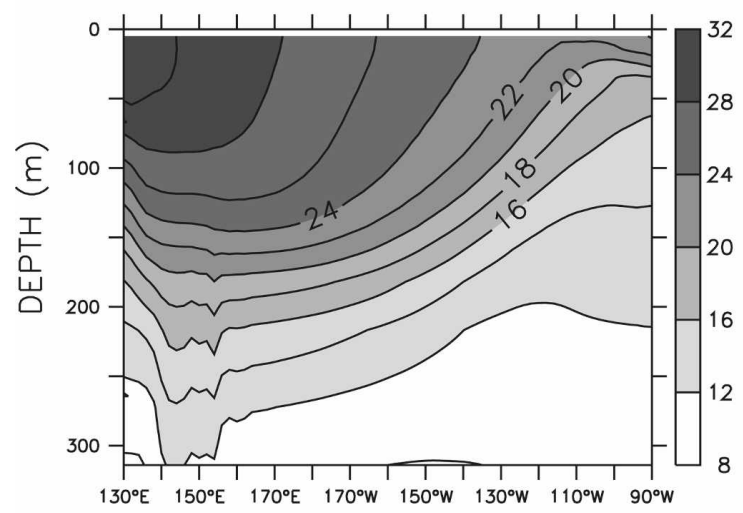

LONGITUDE

(c) $z_{20}(m), 20 c$

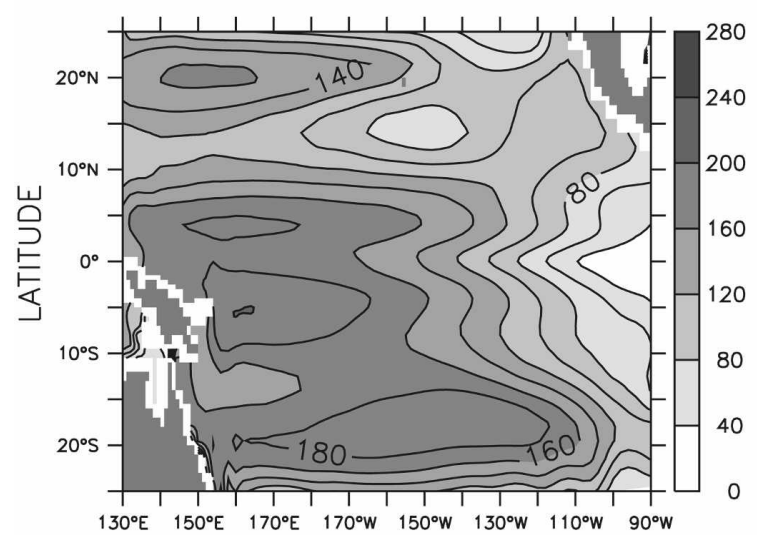

LONGITUDE

(e) Streamfunction (Sv), 20C

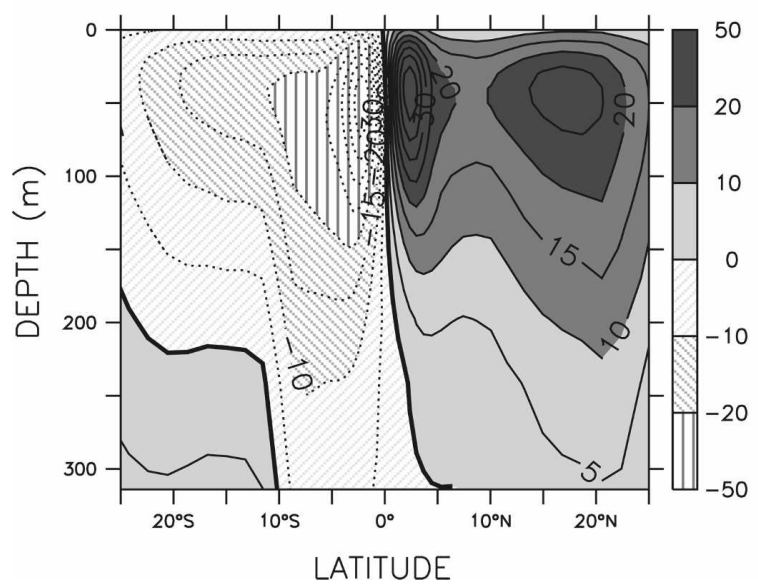

(b) Levitus climatology

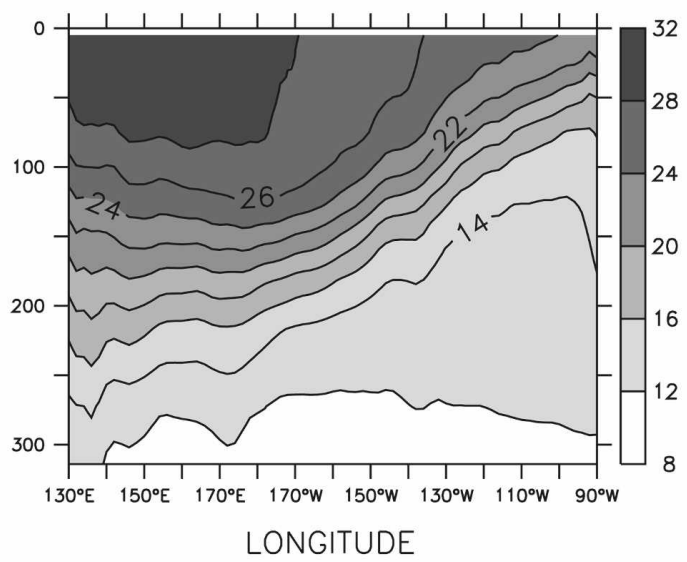

(d) Levitus climatology

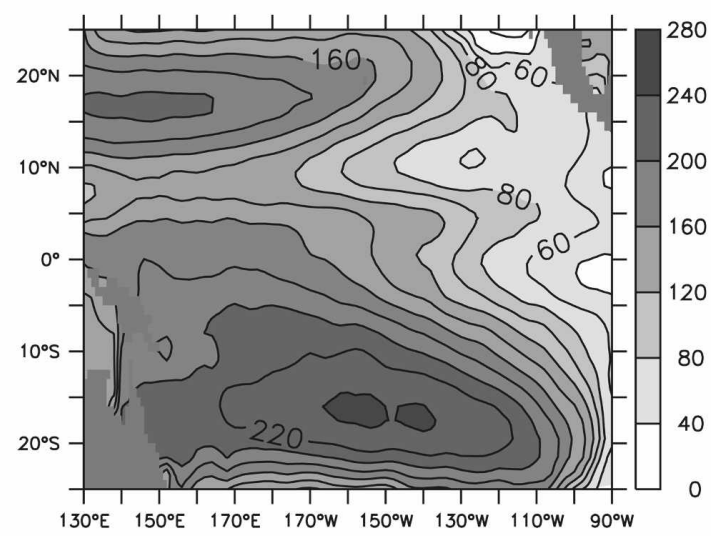

LONGITUDE

(f) Forced ocean

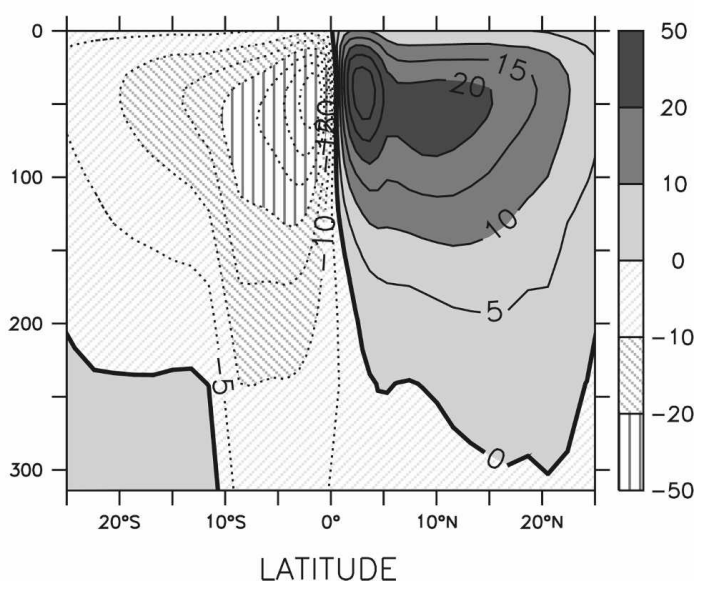

FIG. 5. Annual mean of (a)-(b) vertical temperature $\left({ }^{\circ} \mathrm{C}\right)$ section along the equator $\left(\mathrm{CI}=2^{\circ} \mathrm{C}\right)$ and $(\mathrm{c})-(\mathrm{d}) 20^{\circ} \mathrm{C}$ isotherm depth $(\mathrm{m})$ of the (left) $20 \mathrm{C}$ control simulation $(20 \mathrm{C})$ and (right) observations $(\mathrm{CI}=20 \mathrm{~m})$. (e) Streamfunction $\Psi\left(1 \mathrm{~Sv} \equiv 10^{6} \mathrm{~m}^{3} \mathrm{~s}^{-1}\right)$ over the Pacific domain from coupled run and (f) that from CORE-forced standalone ocean model $(\mathrm{CI}=5 \mathrm{~Sv})$. 

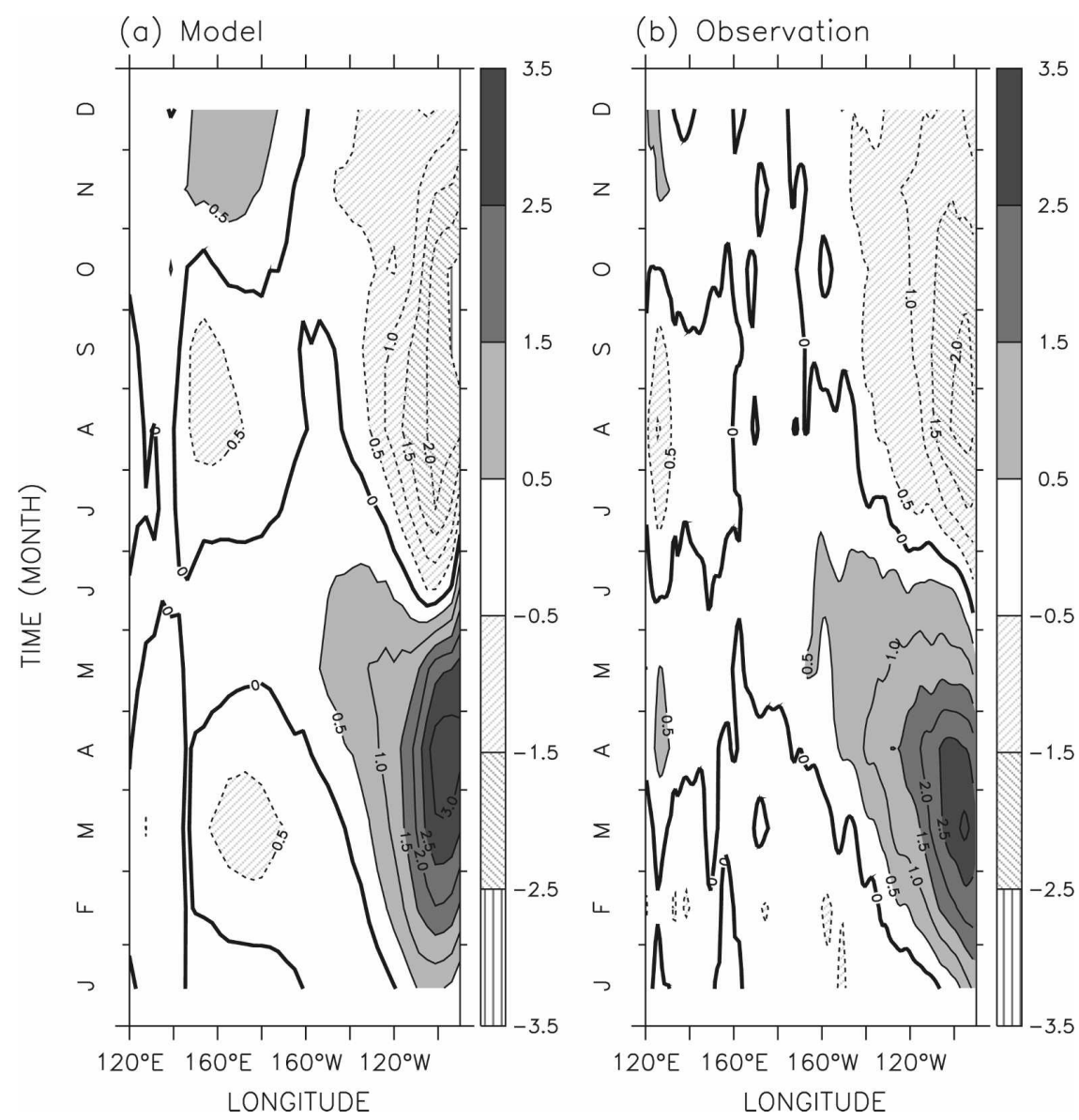

FIG. 6. Hovmoeller diagram of SST anomalies $\left({ }^{\circ} \mathrm{C}\right)$ along the equatorial Pacific from (a) the $20 \mathrm{C}$ control simulation and (b) observations (HadISST, 1870-2004) $\left(\mathrm{CI}=0.5^{\circ} \mathrm{C}\right)$.

interannual variability reasonably. The spatial pattern of the standard deviation agrees reasonably well with observations (Fig. 7). However, KCM produces stronger equatorial SST variability than observed, specifically over the western and central equatorial Pacific and too weak variability near the eastern coast south of $15^{\circ} \mathrm{S}$. A band of too strong variability is simulated in the northern subtropics.

Simulated Niño-3 averaged SST anomalies show clear similarities to observations (Figs. 8a,b). In particular, both have similar amplitude, with the standard deviations of the observed and simulated time series being 0.78 and 0.93 (see Table 1), respectively. Both time series are also quite irregular, with phases of weaker variability broken by a series of stronger events, and have similar spectral characteristics (Fig. 8c). As in observations, the model's dominant spectral peak is found at a period of $4 \mathrm{yr}$. In the model, however, there is greater (less) power in the 2-4 (4-5) yr band compared to observations. This tendency is further enhanced when the statistical cloud cover scheme is not used.
Observed and simulated distributions (histograms) of Niño-3 SST anomalies also agree quite well (see Fig. 16a). However, the occupancy of values close to zero is less in the simulated time series than in observations, and the skewness (kurtosis) of the simulated time series amounts to 0.04 (2.95), which does not correspond well with the observed value of 0.75 (4.13; Table 1). Furthermore, the observed strong phase locking of ENSO to the annual cycle is not captured by KCM: The model simulates a weak semiannual cycle in Niño-3 SST variability (Fig. 8d), with peaks in January-February and July-August, as compared to the pronounced annual cycle in observations, with peak values in DecemberJanuary and a minimum value in April. This is somewhat surprising, as the SST annual cycle in the eastern equatorial Pacific is quite well simulated by KCM. However, as described above the semiannual cycle in SST is relatively strong near the date line and the SST annual cycle in the east lags the observations by one month. Both may contribute to the problem, which will be the subject of future investigation. 


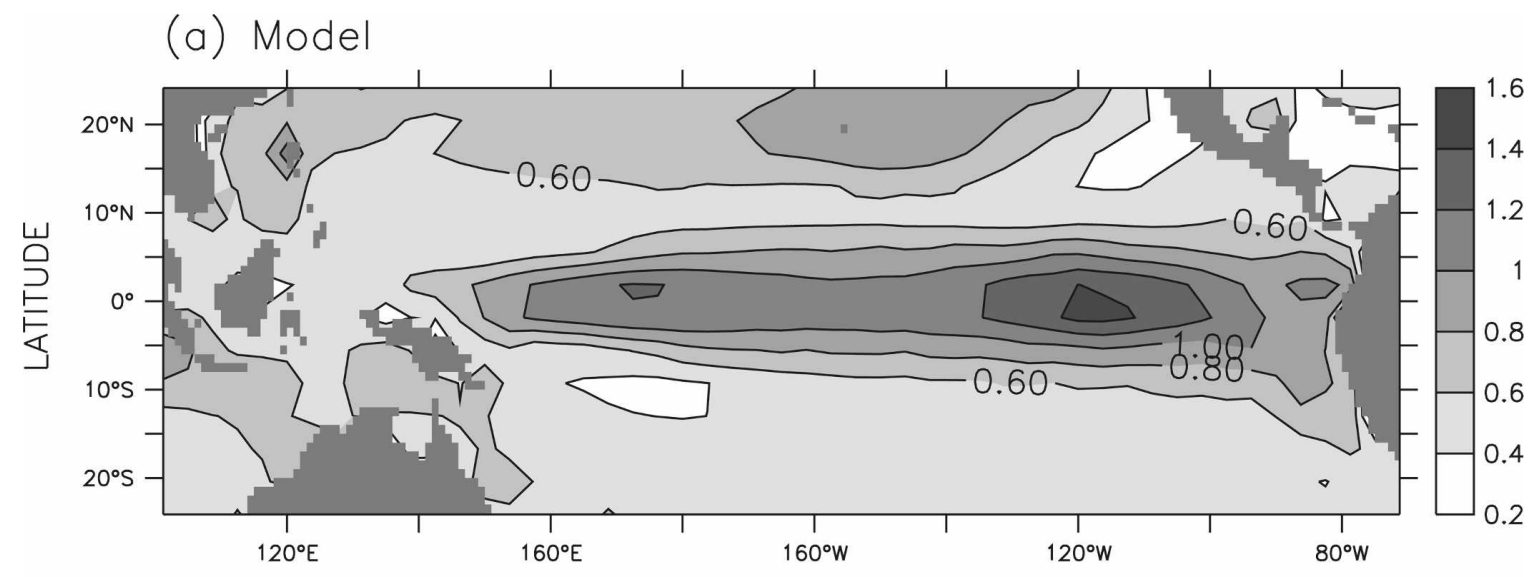

LONGITUDE

(b) Observation

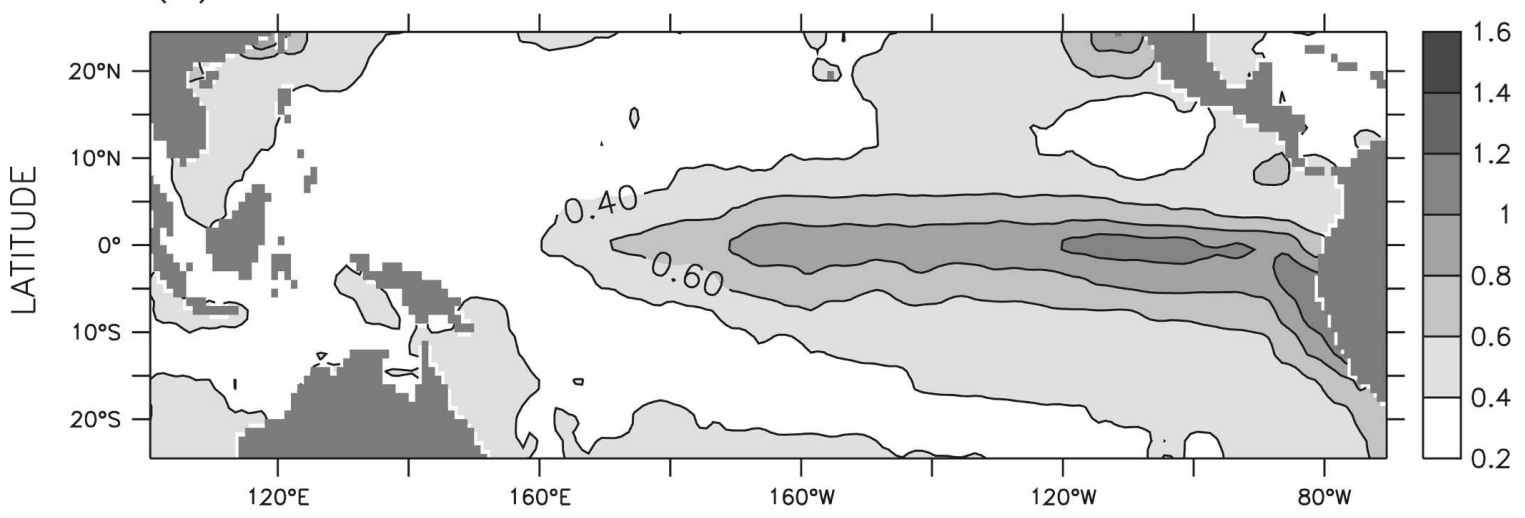

LONGITUDE

FIG. 7. Std dev of SST anomalies $\left({ }^{\circ} \mathrm{C}\right)$ from (a) the $20 \mathrm{C}$ control simulation (330 yr) and (b) observations (HadISST, 1870-2004).

Hovmoeller diagrams of anomalies in zonal surface wind, $20^{\circ} \mathrm{C}$ isotherm depth (a measure of upper-ocean heat content) and SST along the equator (Fig. 9) show key similarities to observations. First, prior to El Niño events there is a build up of equatorial heat content. This is most clearly seen by the positive heat content anomalies in the west (Fig. 9b). These anomalies propagate eastward, strengthening as they go. They lead to SST anomalies in the eastern Pacific (Fig. 9c) that are associated with westerly wind anomalies over the western and central Pacific (Fig. 9a), indicating remote wind stress forcing. The lag correlation between warm water volume (WWV) integrated over the tropical Pacific $\left(5^{\circ} \mathrm{S}-5^{\circ} \mathrm{N}, 120^{\circ} \mathrm{E}-80^{\circ} \mathrm{W}\right)$ are maximum when WWV leads Niño-3 SST anomalies by seven months (not shown); the maximum correlation in the model (0.6) is slightly weaker than in observations (0.7). Thus, the dynamics of the simulated ENSO appear to be in agreement with the recharge-discharge theory of Jin (1997), and suggest the dominance of the thermocline feedback in the model.

The Hovmoeller diagrams also suggest an SST-mode character to the ENSO variability: in particular, SST anomalies clearly propagate westward, although there are some hints of eastward propagation in the zonal wind. In observations, both eastward and westward propagation of SST anomalies is found, with indications that weak (strong) events propagate westward (eastward). Results from theoretical work argue that these changes in east-west propagation characteristics reflect shifts from a more thermocline-driven subsurface mode to a more SST-zonal-current-driven surface mode (Fedorov and Philander 2001). In the model it appears that the SST-mode component is stronger than that in observations. Nonetheless, the results suggest the thermocline feedback dominates in KCM, because the zonal winds do not exhibit the characteristics of an SST mode being dominated by stationary anomalies in the 
(a) Nino3 SSTa, Model (330yrs)

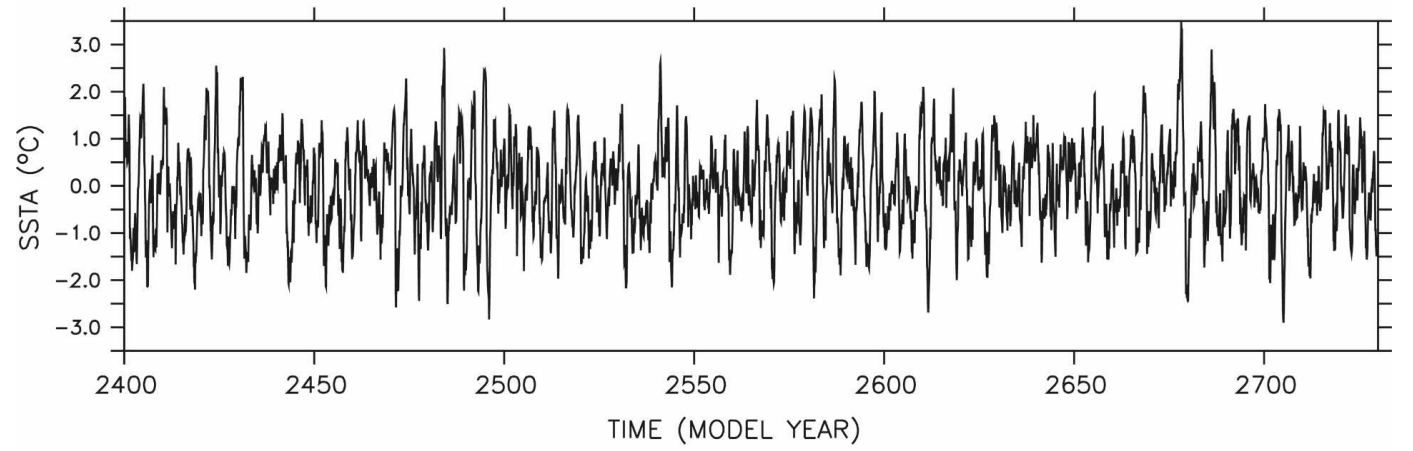

(b) Observation (HadISST, 1870-2004)

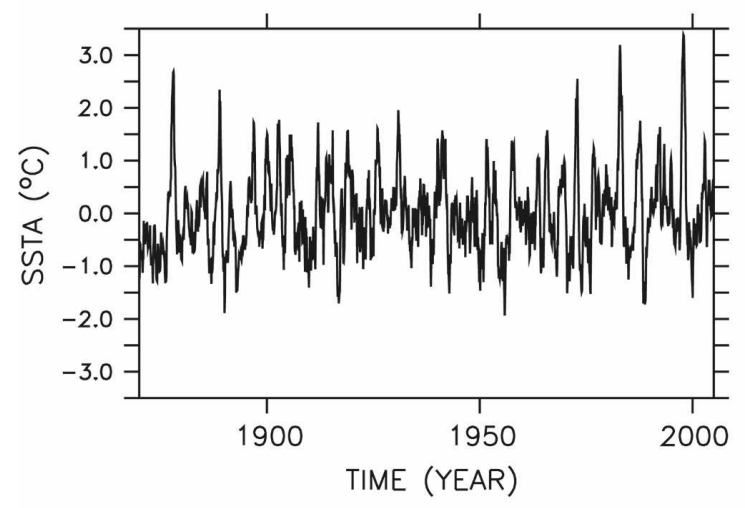

(d) Standard deviation

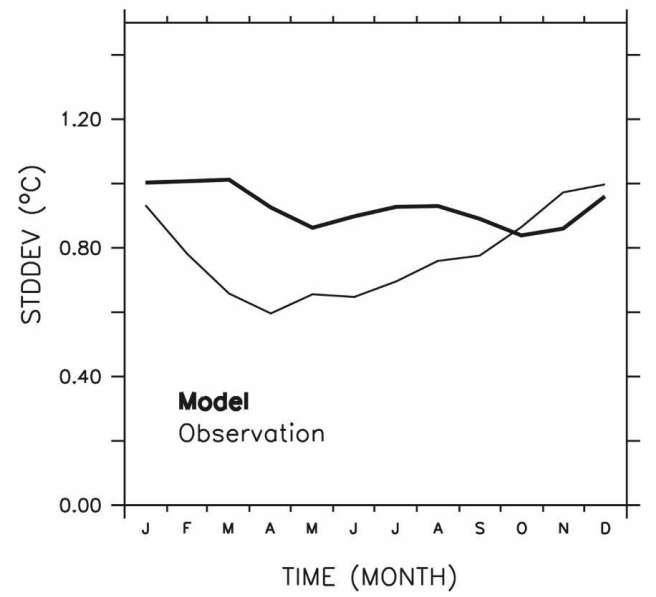

(c) Nino3 SSTa spectra

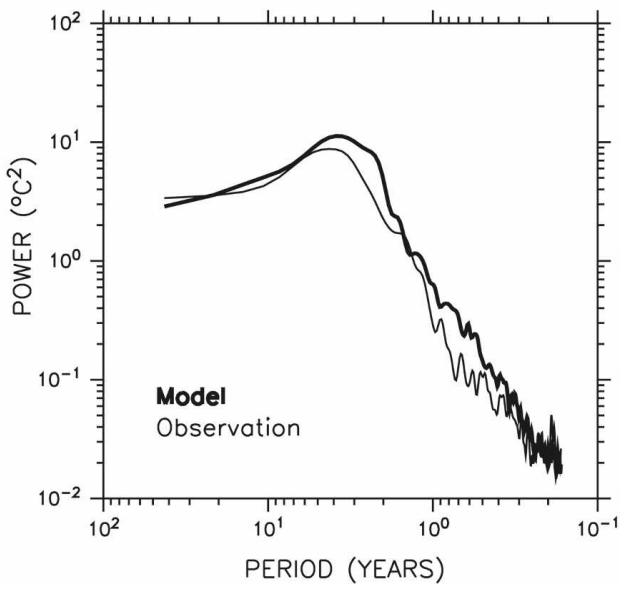

FIG. 8. Niño-3 SST anomaly $\left({ }^{\circ} \mathrm{C}\right)$ time series of (a) $20 \mathrm{C}$ control simulation and (b) observations (HadISST, 18702004), and (c) corresponding spectra $\left({ }^{\circ} \mathrm{C}^{2}\right)$ and (d) monthly std devs $\left({ }^{\circ} \mathrm{C}\right)$ (thin line: observation; thick line: model).

west. Furthermore, as pointed out by Neelin et al. (1994), ENSO in the real world is most likely a mixed surface/subsurface dynamics mode that involves elements of both extreme cases.

Several other features are noteworthy in the Hovmoeller diagrams. First, in difference to observations, simulated SST anomalies (Fig. 9c) are generally stron- ger in the central Pacific, rather than in the east (Fig. 9f). Second, as seen in observations and already mentioned above, the model realistically simulates quiescent periods. Third, superimposed on the slow ENSO variability, a great deal of intraseasonal variability is seen in the wind, $20^{\circ} \mathrm{C}$-isotherm depth, and SST variability. This variability may contribute to 
TABle 1. Basic statistics of Niño-3 SST anomalies. Confidence interval represents one standard deviation of the eight ensemble members.

\begin{tabular}{lccrc}
\hline \hline & \multirow{2}{*}{$\begin{array}{c}\text { Observation } \\
\text { (HadISST, }\end{array}$} & \multicolumn{2}{c}{ 20C } & \\
\cline { 3 - 4 } & 1870-2004) & $330 \mathrm{yr}$ & $30-\mathrm{yr}$ chunks & 21C \\
\hline Std dev & 0.78 & 0.93 & $0.91 \pm 0.15$ & $1.15 \pm 0.27$ \\
Skewness & 0.75 & 0.04 & $-0.03 \pm 0.21$ & $0.28 \pm 0.39$ \\
Kurtosis & 4.13 & 2.95 & $2.60 \pm 0.31$ & $3.60 \pm 0.87$ \\
\hline
\end{tabular}

the realistic irregular nature of the simulated ENSO variability.

Finally, the ENSO global teleconnection pattern is investigated. The regression of simulated monthly Niño-3 SST anomalies onto sea level pressure anomalies shows the clear Southern Oscillation seesaw pattern over the tropics, which corresponds quite well to observations (Fig. 10). Explained variance over the eastern tropical Pacific is greater than $30 \%$ in the simulation, slightly lower than that of observation $(40 \%)$. However, the meridional width is narrower in the model. The teleconnection to Northern and Southern Hemisphere extratropics compares quite well to observations, although the teleconnection to the Northern (Southern) Hemisphere may be overestimated (underestimated). However, one has to keep in mind that the observational data are much shorter than that of the model. Thus, KCM is able to realistically simulate ENSO dynamics and capture the major atmospheric teleconnection patterns.

\section{Response to global warming}

\section{a. Change of mean state}

As described above, KCM simulates tropical Pacific climate and variability reasonably well. The response of both to global warming is now described. Global mean SAT changes in the $21 \mathrm{C}$ greenhouse warming simulations are shown in Fig. 2 (see section 2) together with SAT simulated in the control simulation. Allowing for the inertia of the climate system, global mean SAT increases rather linearly with respect to $\mathrm{CO}_{2}$ concentration until the time of $\mathrm{CO}_{2}$ doubling. Although $\mathrm{CO}_{2}$ concentration is fixed after doubling is reached, the global mean SAT still increases, but at a slower rate. We note, however, that equilibrium was not reached at the end of the $21 \mathrm{C}$ simulations. The transient climate response (TCR; Cubasch et al. 2001), defined as the global mean surface air temperature change averaged over a 20 -yr period centered at the time of $\mathrm{CO}_{2}$ doubling (from year 61 to 80 ), is $2.9^{\circ} \mathrm{C}$, which is stronger than those $\left(1.2^{\circ}-2.6^{\circ} \mathrm{C}\right)$ of the IPCC models (Table 8.2 in Solomon et al. 2007).

The ensemble mean surface temperature response pattern is shown in Fig. 11, defined as the difference between the last $30 \mathrm{yr}$ of the $21 \mathrm{C}$ integrations and the control simulation. Consistent with virtually all climate models, a strong land-sea contrast is simulated by $\mathrm{KCM}$. The warming exceeds $6^{\circ} \mathrm{C}$ in the high latitudes of the Northern Hemisphere, specifically over parts of Eurasia and North America. Over the North Atlantic Ocean, the warming is rather small on average, with a small region of cooling near $50^{\circ} \mathrm{N}$ due to a substantial weakening of the MOC. The warming over the Southern Ocean is also rather weak, in accord with most other climate models.

The equatorial Pacific surface temperature increases by about $3^{\circ} \mathrm{C}$, which is generally higher than the warming over the subtropical and midlatitudinal Pacific Ocean. One important exception is the northwestern subtropical Pacific, where the warming attains a similar strength. We shall return to this point below when discussing the changes in the subtropical cells. Although slightly stronger in the west, the warming at the equator is almost zonally symmetric: Maximum warming in the east and west are $3.0^{\circ}$ and $3.2^{\circ} \mathrm{C}$, respectively. In terms of the "ENSO-ness" index, defined as the pattern correlation between the SST trend and first EOF of SST anomalies in the equatorial region $\left(10^{\circ} \mathrm{S}-10^{\circ} \mathrm{N}, 120^{\circ} \mathrm{E}-\right.$ $80^{\circ} \mathrm{W}$ ), our change equals 0.3 , which corresponds to a weakly "El Niño-like" response and is smaller than that of most models (Fig. 10.16 in Solomon et al. 2007). In the vertical, the temperature increase is larger near the surface and less pronounced in deeper levels (Fig. 12a), which enhances the vertical gradient in the region of the thermocline (Fig. 5a) and thus sharpens it. The sharpness of the thermocline is an important parameter controlling ENSO characteristics (Fedorov and Philander 2001; Meehl et al. 2001), and as described below, contributes to the changes in ENSO simulated in response to global warming.

The zonal wind stress is reduced over the western and eastern equatorial Pacific, while it is increased over the central equatorial Pacific (Fig. 12c). A reduced equatorial zonal wind stress, that is, weakened trade winds, weakens the Ekman transport divergence and hence the equatorial upwelling, which as a consequence is responsible for the enhanced warming over the western and eastern parts. The stronger zonal wind stress over the central part, on the other hand, enhances upwelling, which explains the local minimum of warming in this region. The $Z_{20}\left(20^{\circ} \mathrm{C}\right.$ isotherm depth) along the equator increases by $9 \mathrm{~m}$ on average, with a slightly larger increase in the west and east of around $15 \mathrm{~m}$, 


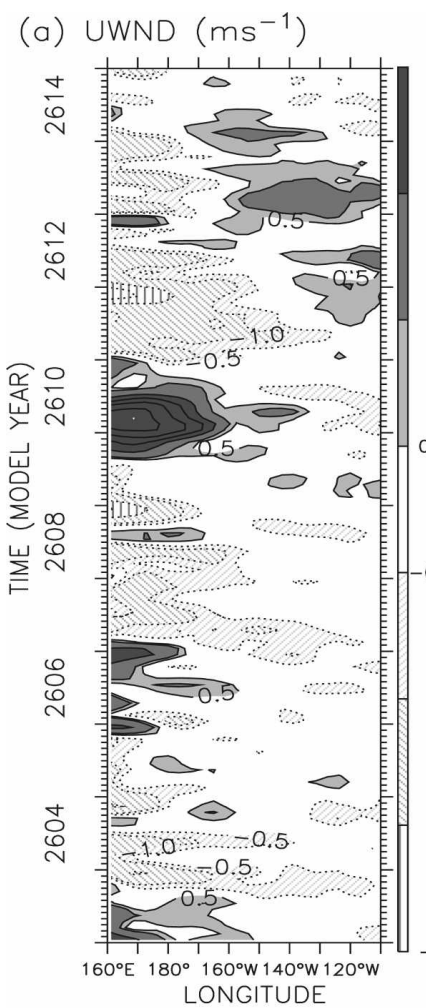

(b) $Z_{20}(m)$

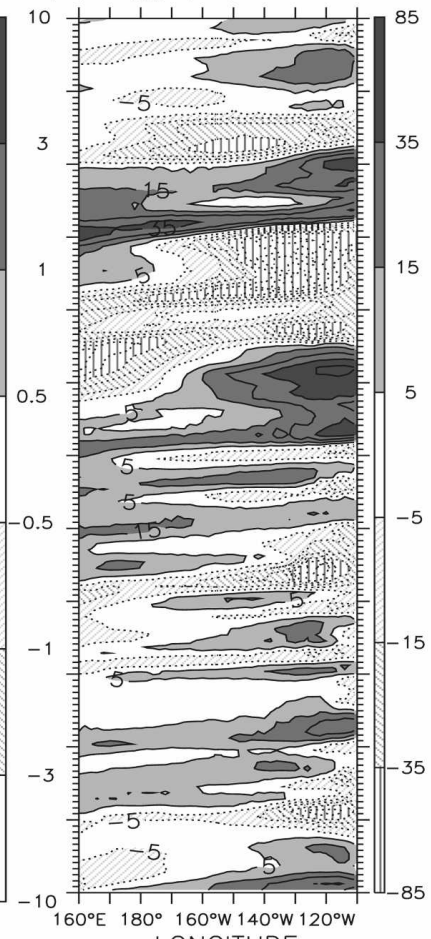

(d) UWND $\left(\mathrm{ms}^{-1}\right)$

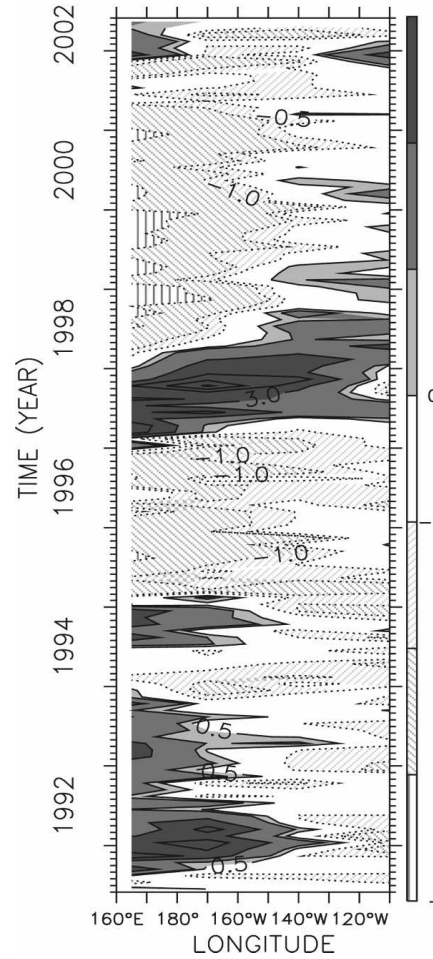

(e) $Z_{20}(m)$

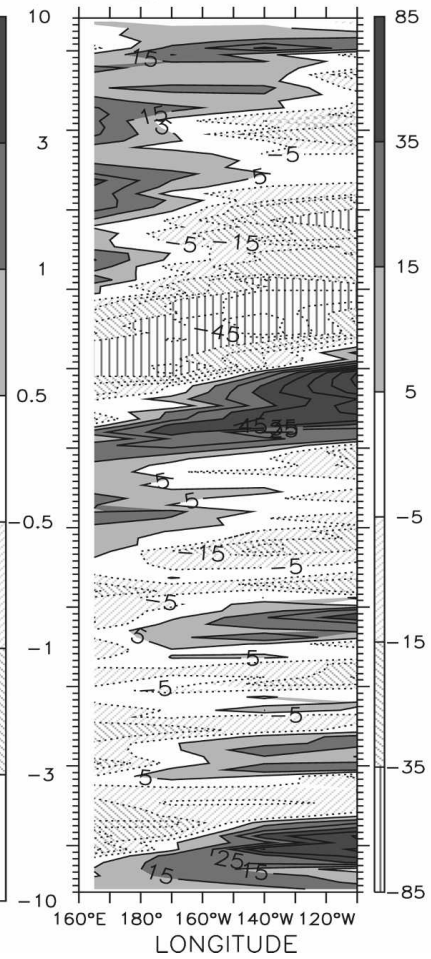

(c) SST $\left({ }^{\circ} \mathrm{C}\right)$

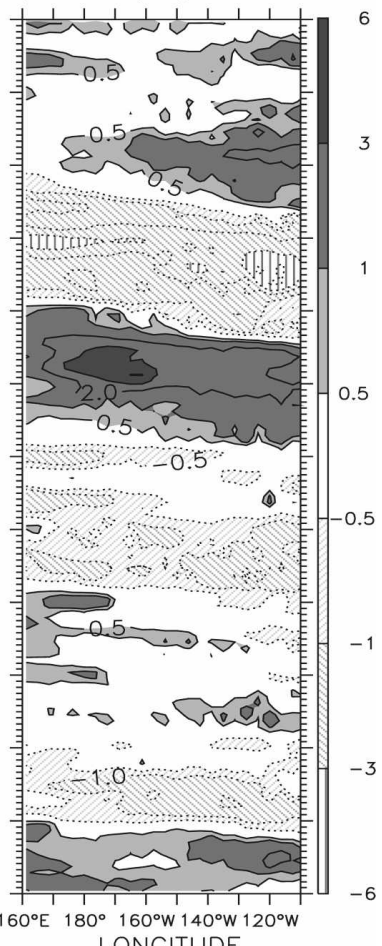

LONGITUDE

(f) SST $\left({ }^{\circ} \mathrm{C}\right)$

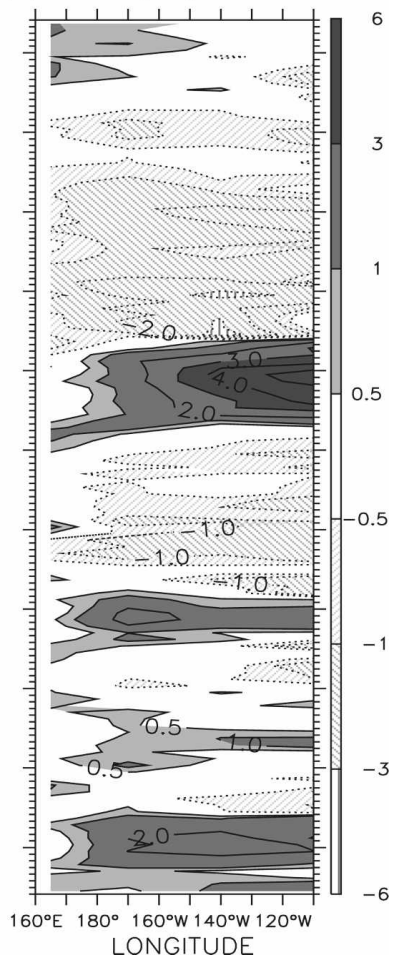

Fig. 9. Anomalies along the equator of (a), (d) 10-m eastward zonal wind speed $\left(\mathrm{m} \mathrm{s}^{-1}\right)$; (b), (e) $20^{\circ} \mathrm{C}$ isotherm depth (m); and (c), (f) SST $\left({ }^{\circ} \mathrm{C}\right)$ from (top) the $20 \mathrm{C}$ control simulation and (bottom) observations (TOGA TAO; McPhaden et al. 1998). 
(a)

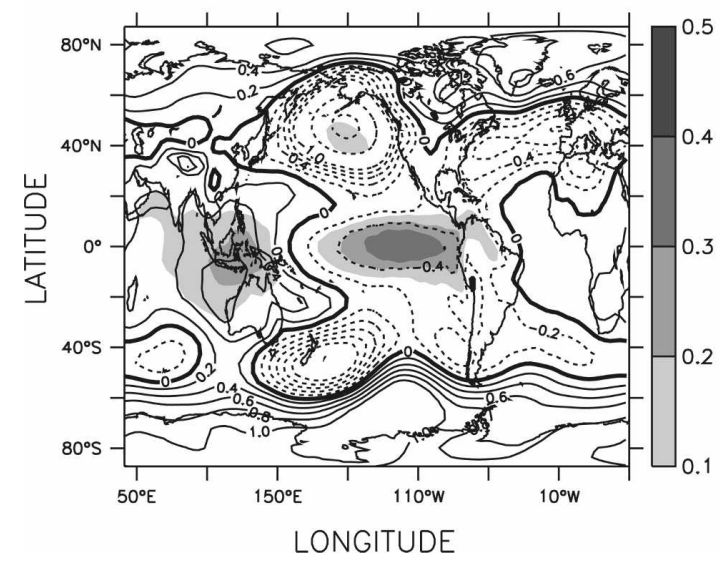

(b)

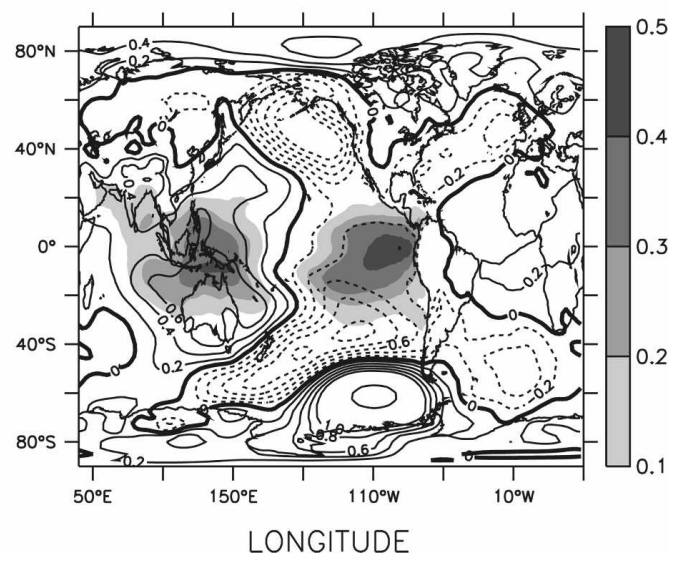

Fig. 10. Regression ( $\mathrm{hPa}{ }^{\circ} \mathrm{C}^{-1}$; contours; $\mathrm{CI}=0.2 \mathrm{hPa}{ }^{\circ} \mathrm{C}^{-1}$ between -1 and 1,1 elsewhere) and explained variance (shading) of monthly anomalies of Niño-3 SST onto sea level pressure: (a) 20C control simulation (330 yr) and (b) observations (55 yr of NCEP-NCAR reanalysis sea level pressure and HadISST Niño-3 SST).

because of surface warming and weakened upwelling (Fig. 12d). The equatorial wind stress changes discussed above are also reflected in the isotherm depth changes. The isotherm depth becomes shallower around $5^{\circ} \mathrm{N}$ in the longitude band $160^{\circ}-120^{\circ} \mathrm{W}$, and in the region $5^{\circ}-$ $10^{\circ} \mathrm{S}$ in the band $180^{\circ}-110^{\circ} \mathrm{W}$. The response of the wind stress curl on both hemispheres is quite patchy (Fig. 12c) but is negative when integrated zonally over the Pacific basin (not shown).

Figure $12 \mathrm{~b}$ shows the response pattern of the meridional overturning streamfunction $\Psi$, which is quite complicated. To ease interpretation, Fig. 13 displays the

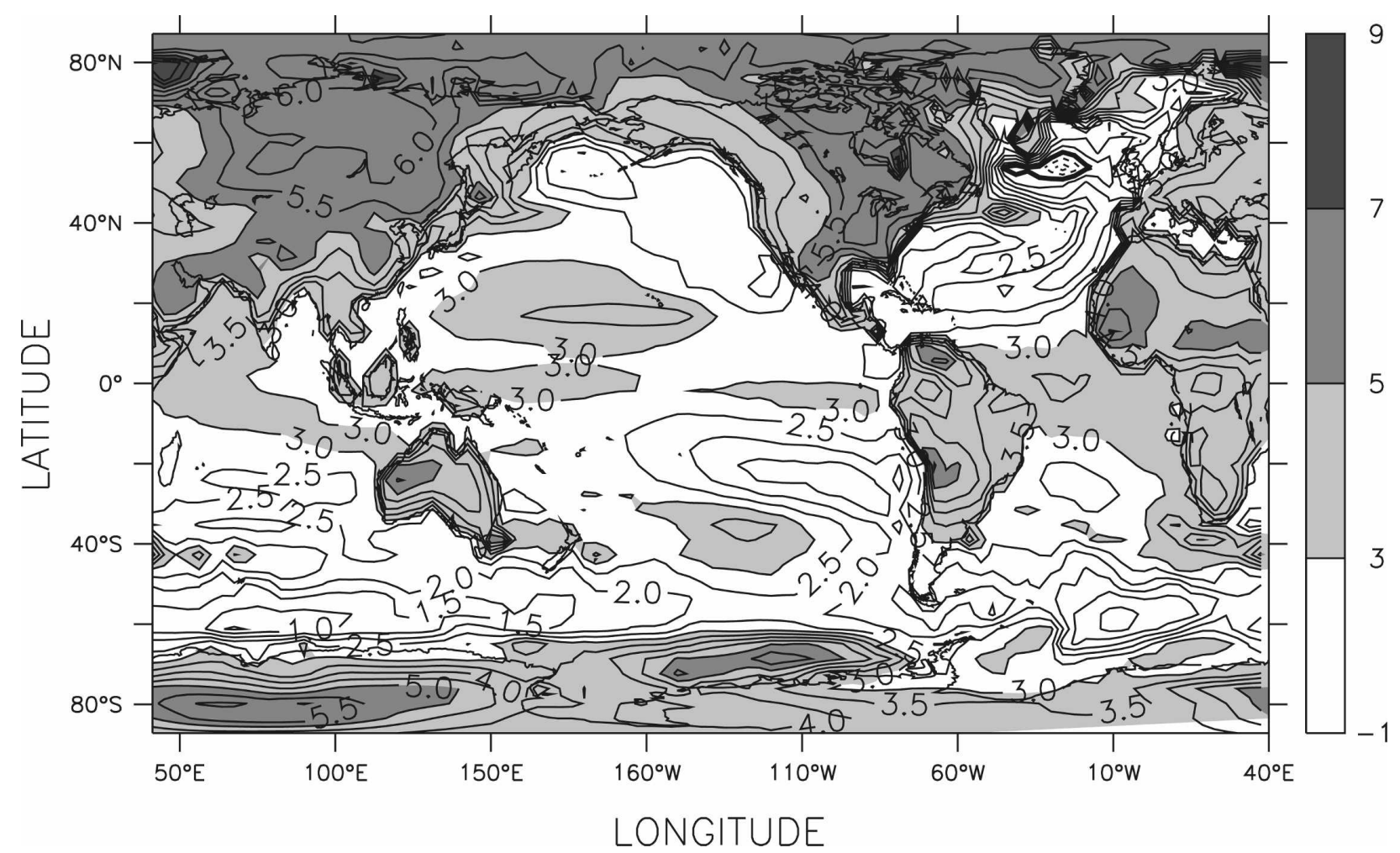

FIG. 11. Ensemble mean response of surface temperature $\left({ }^{\circ} \mathrm{C}\right)$ from the eight members of $21 \mathrm{C}$ global warming experiments $(\mathrm{CI}=$ $0.5^{\circ} \mathrm{C}$ ). Last $30 \mathrm{yr}$ (year $71-100$ ) from $21 \mathrm{C}$ experiments are used for the calculation. 
(a) Temperature $\left({ }^{\circ} \mathrm{C}\right)$

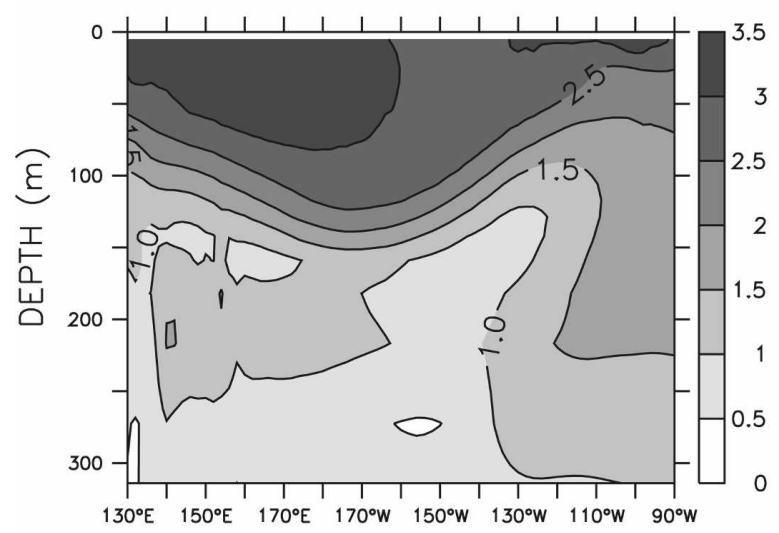

LONGITUDE

(c) Wind stress curl $\left(10^{-8} \mathrm{Nm}^{-3}\right)$

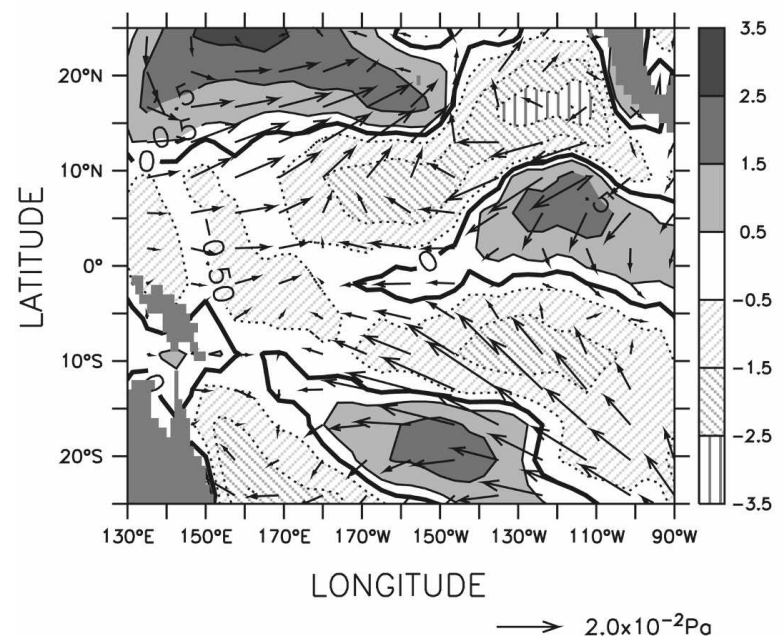

(b) Streamfunction (Sv)

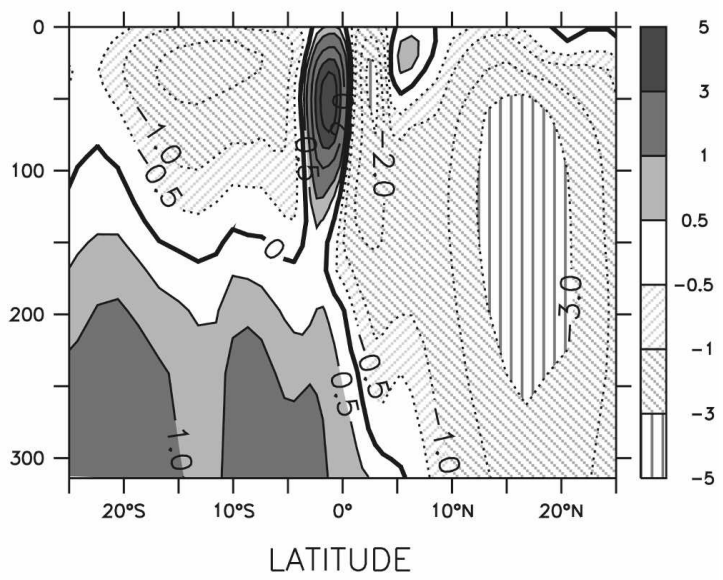

(d) $Z_{20}(m)$

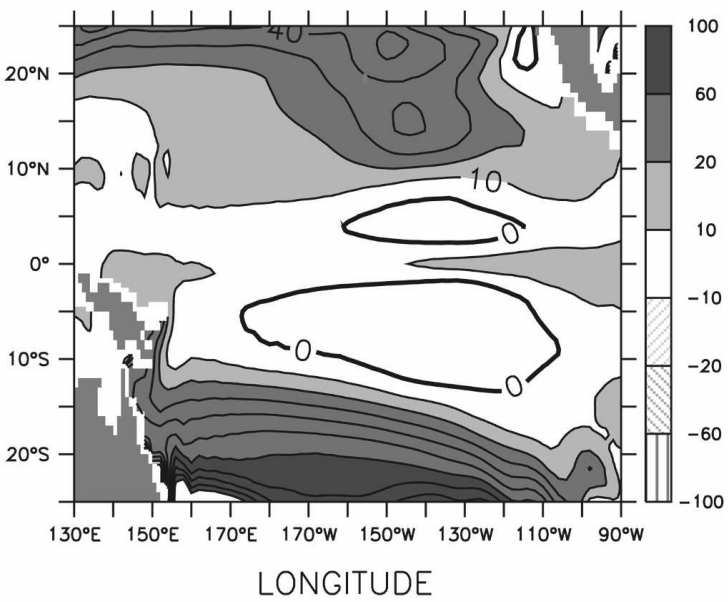

FIG. 12. Ensemble mean responses (last $30 \mathrm{yr}$ of $21 \mathrm{C}$ experiments) of (a) temperature $\left({ }^{\circ} \mathrm{C}\right)$ along the equator, (b) Pacific streamfunction, $\Psi(\mathrm{Sv})(\mathrm{CI}=0.5 \mathrm{~Sv}$ between -1 and 1,1 elsewhere $)$, (c) wind stress (arrow) $\left(2 \times 10^{-2} \mathrm{~Pa}\right)$ and its curl $\left(10^{-8} \mathrm{~N} \mathrm{~m}^{-3}\right)$, and (d) $20^{\circ} \mathrm{C}$ isotherm depth $(\mathrm{m})(\mathrm{CI}=10 \mathrm{~m})$.

time evolutions of the tropical cells (TCs) and STCs from the control simulation and the ensemble of $\mathrm{CO}_{2}$ experiments. TC and STC indexes are defined accord- ing to Lohmann and Latif (2005) by the zonally averaged Pacific meridional overturning streamfunction, $\Psi$, as

$$
\begin{aligned}
\mathrm{TC} & =\Psi_{\max }\left(5^{\circ} \mathrm{S}-5^{\circ} \mathrm{N}, \text { upper } 250 \mathrm{~m}\right)-\Psi_{\min }\left(5^{\circ} \mathrm{S}-5^{\circ} \mathrm{N}, \text { upper } 250 \mathrm{~m}\right) \text { and } \\
\mathrm{STC} & =\Psi_{\max }\left(10^{\circ}-30^{\circ} \mathrm{N}, \text { upper } 250 \mathrm{~m}\right)-\Psi_{\min }\left(10^{\circ}-30^{\circ} \mathrm{S}, \text { upper } 250 \mathrm{~m}\right) .
\end{aligned}
$$

TC strength is clearly reduced by about $10 \%$ on average in the $21 \mathrm{C}$ integrations (Fig. 13a), most likely because of the changes in equatorial zonal wind stress described above. STC strength, however, is not significantly changed (Fig. 13b). Yet, when we separate STC strength into its Northern and Southern Hemisphere components, considerable changes become apparent.
While the Northern Hemisphere cell is reduced (Fig. 13c), the Southern Hemisphere cell is strengthened relative to the control run (Fig. 13d). Please note the different signs of the northern and southern cells in terms of the streamfunction. Thus both cells respond to global warming, but there is a strong cancellation between the changes in the two cells, so that the net 
(a) TC index

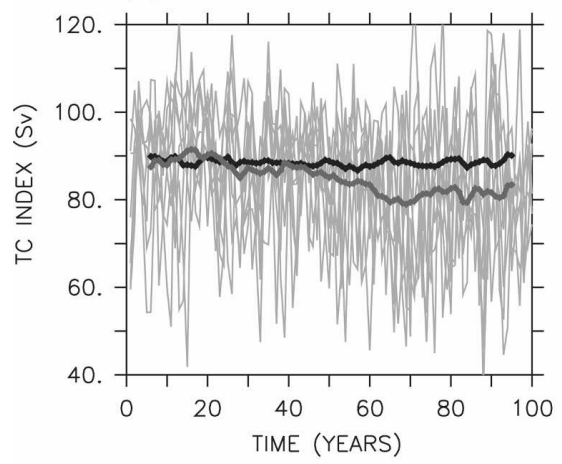

(c) NH STC

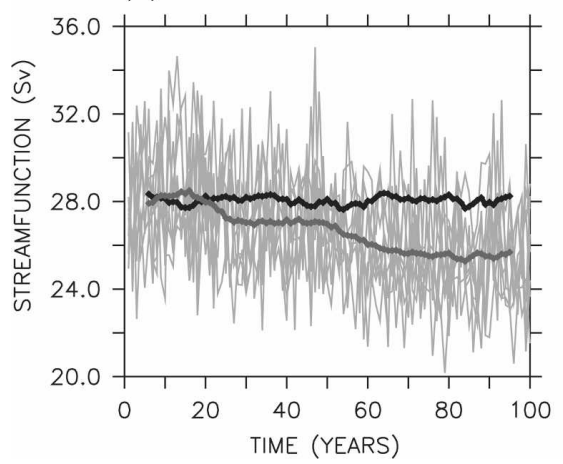

(b) STC index

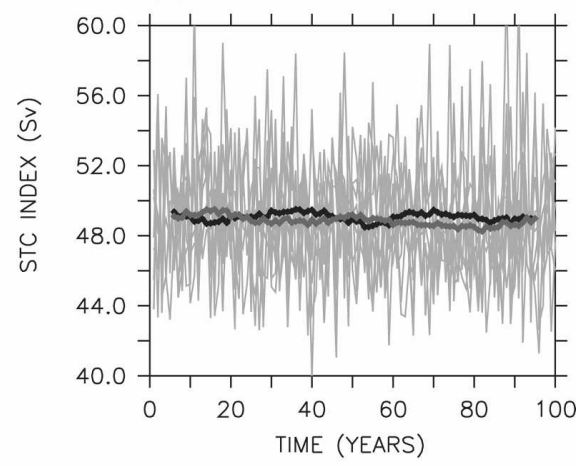

(d) SH STC

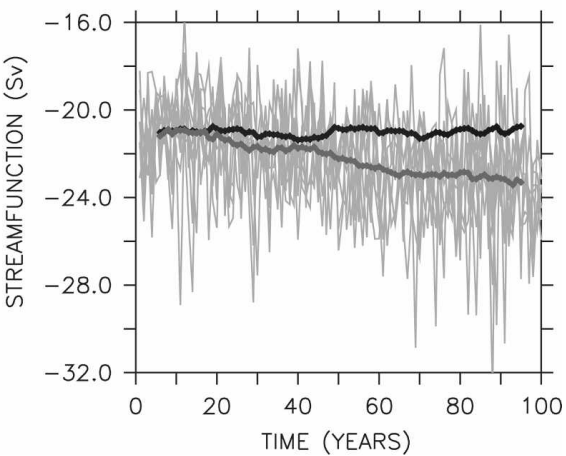

FIG. 13. Evolution of (a) tropical and (b) subtropical cell indices (Sv) of 20C control (thick black lines) and $21 \mathrm{C}$ global warming experiments (thick gray lines). Thick lines represent 11-yr running averaged ensemble mean and thin gray lines annual values of the $21 \mathrm{C}$ ensemble members. Tropical and subtropical cell index, which represent strength of off-equatorial circulation, are defined as $\Psi_{\max }\left(5^{\circ} \mathrm{S}-5^{\circ} \mathrm{N}\right.$, upper $\left.250 \mathrm{~m}\right)-\Psi_{\min }\left(5^{\circ} \mathrm{S}-5^{\circ} \mathrm{N}\right.$, upper $\left.250 \mathrm{~m}\right)$ and $\Psi_{\max }\left(10^{\circ}-30^{\circ} \mathrm{N}\right.$, upper $\left.250 \mathrm{~m}\right)-\Psi_{\min }\left(10^{\circ}-30^{\circ} \mathrm{S}\right.$, upper $\left.250 \mathrm{~m}\right)$, respectively. (c) Maximum streamfunction (Sv) of Northern Hemisphere subtropical cell and (d) minimum streamfunction of Southern Hemisphere subtropical cell (note that minimum streamfunction for Southern Hemisphere indicates maximum poleward streamfunction; see Fig. 5e).

change is very small. The spatial response pattern of the overturning (Fig. 12b) indicates a shallow Southern Hemisphere and a deep Northern Hemisphere cell response.

We can understand the northern and southern STC responses by the SST and wind stress curl changes (Figs. 11, 12c). As already noted above, the northern subtropics exhibit relatively strong warming in the west and central part. In contrast, the eastern and central southern subtropics show a much reduced warming. The different SST response can be explained by the changes in the trade winds of both hemispheres. While they strengthen in the southeastern subtropical Pacific, they weaken in the northwestern Pacific (Fig. 12c), changing surface wind speed, evaporation, and vertical mixing in the ocean. The opposite changes in evaporation and vertical mixing in the northern and southern subtropics explain the different SST response in these two regions. Thus as density in low latitudes is mostly temperature driven, the warming (cooling) in the northern (southern) subtropics implies reduced (enhanced) forcing of the northern (southern) STC. Furthermore, the response in the zonally integrated wind stress curl near $10^{\circ} \mathrm{N}$ and $10^{\circ} \mathrm{S}$ (not shown) is negative and thus also contributes to the hemispheric differences in the STC response. The mechanism behind the STC changes in KCM, however, may not act in other models.

\section{b. Change of ENSO}

Figure 14 shows the evolution of Niño-3 SST anomalies from the eight $21 \mathrm{C}$ experiments with different initial conditions. The ensemble mean temperature evolution in the Niño-3 region smoothed with a 10-yr running mean filter shows a clear increase of about $3^{\circ} \mathrm{C}$, with some tendency for equilibration toward the end of the integrations. Interannual variability also increases in the second half of the integrations. The ensemble 


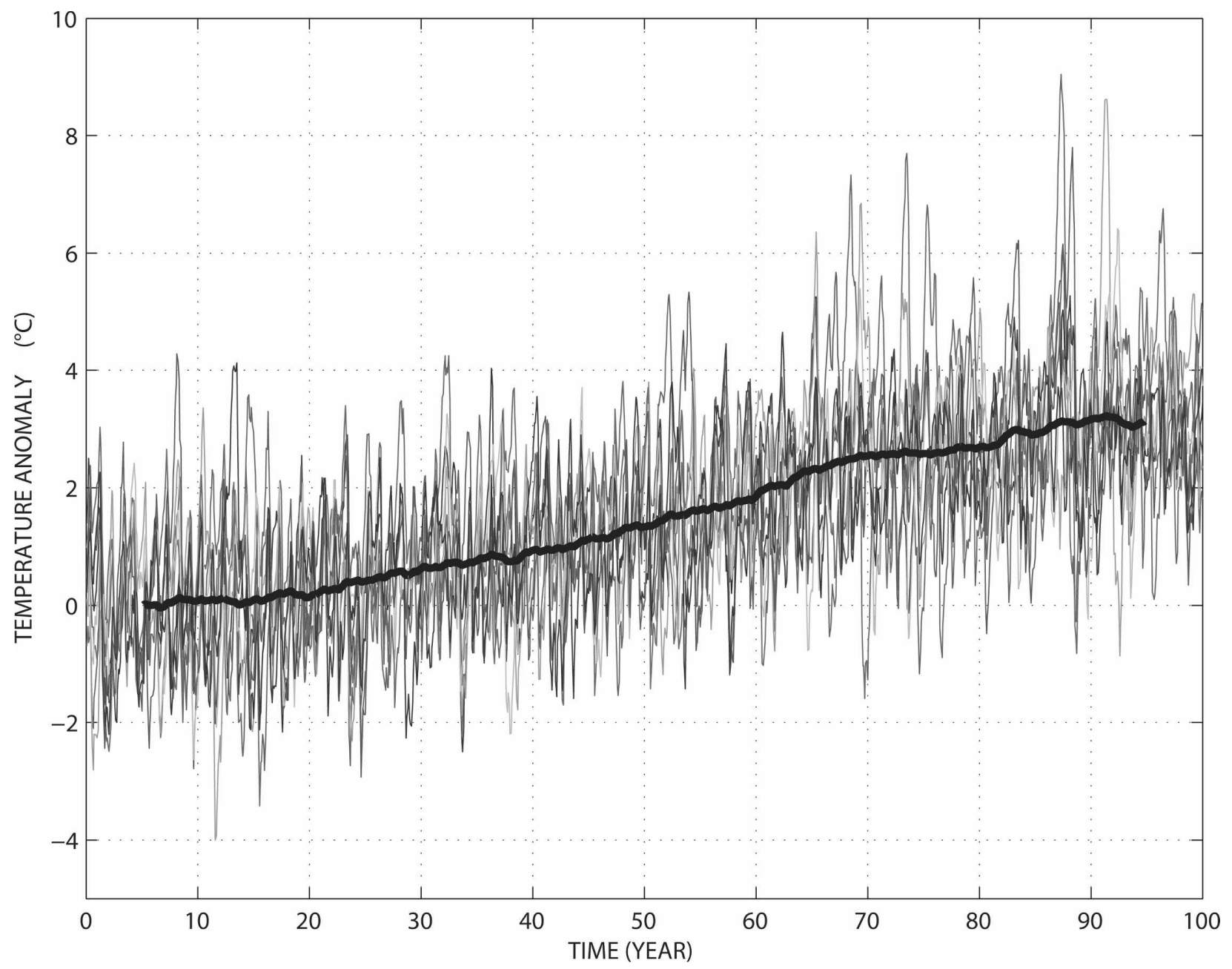

FIG. 14. Evolution of Niño-3 SST anomalies $\left({ }^{\circ} \mathrm{C}\right)$ from the eight members of $21 \mathrm{C}$ experiments. The thick line represents the ensemble mean smoothed with a 10 -yr running mean filter.

mean standard deviation of Niño-3 averaged SST anomalies for the last $30 \mathrm{yr}$ is $1.15^{\circ} \mathrm{C}$. This represents a $26 \%$ increase from that of the $20 \mathrm{C}$ control simulation (0.91) and is well outside one standard deviation confidence interval (Table 1). The response, however, varies quite strongly among the ensemble members. Spectral analysis was performed to identify the response in the frequency domain (Fig. 15). To account for the inertia of the coupled system, spectra were calculated from the last $30 \mathrm{yr}$ of the $21 \mathrm{C}$ integrations. They were calculated for each realization, and then averaged to obtain an ensemble mean spectrum. A spectrum for the $20 \mathrm{C}$ control simulation was calculated similarly, by taking eight $30-y r$ chunks from the run with no overlap. We note that the control run spectrum obtained from the eight overlapping 30 -yr chunks is very similar to the spectrum shown in Fig. 8c determined from the full 330-yr-long control simulation. One standard deviation of the ensemble spread is used here as a rough uncertainty estimate for both the $20 \mathrm{C}$ and $21 \mathrm{C}$ simulations. The ensemble mean spectrum of the $21 \mathrm{C}$ integrations displays an increase in variability that is most pronounced at interannual time scales (Fig. 15). At the ENSO peak period of about $4 \mathrm{yr}$, the increase in power amounts to double. The overall shape of the spectrum does not change much, and the ENSO period remains almost constant at about $4 \mathrm{yr}$, although a small shift to a longer period is simulated. Finally, ENSO remains a broadband phenomenon in the frequency domain in the $21 \mathrm{C}$ integrations. We did not assess the statistical significance of the results, but the pure fact that the change extends over the whole frequency domain is not expected only because of sampling errors. We note, however, that an ensemble of reasonable size is needed to detect the changes in variability: not every individual ensemble member does show an obvious increase as 


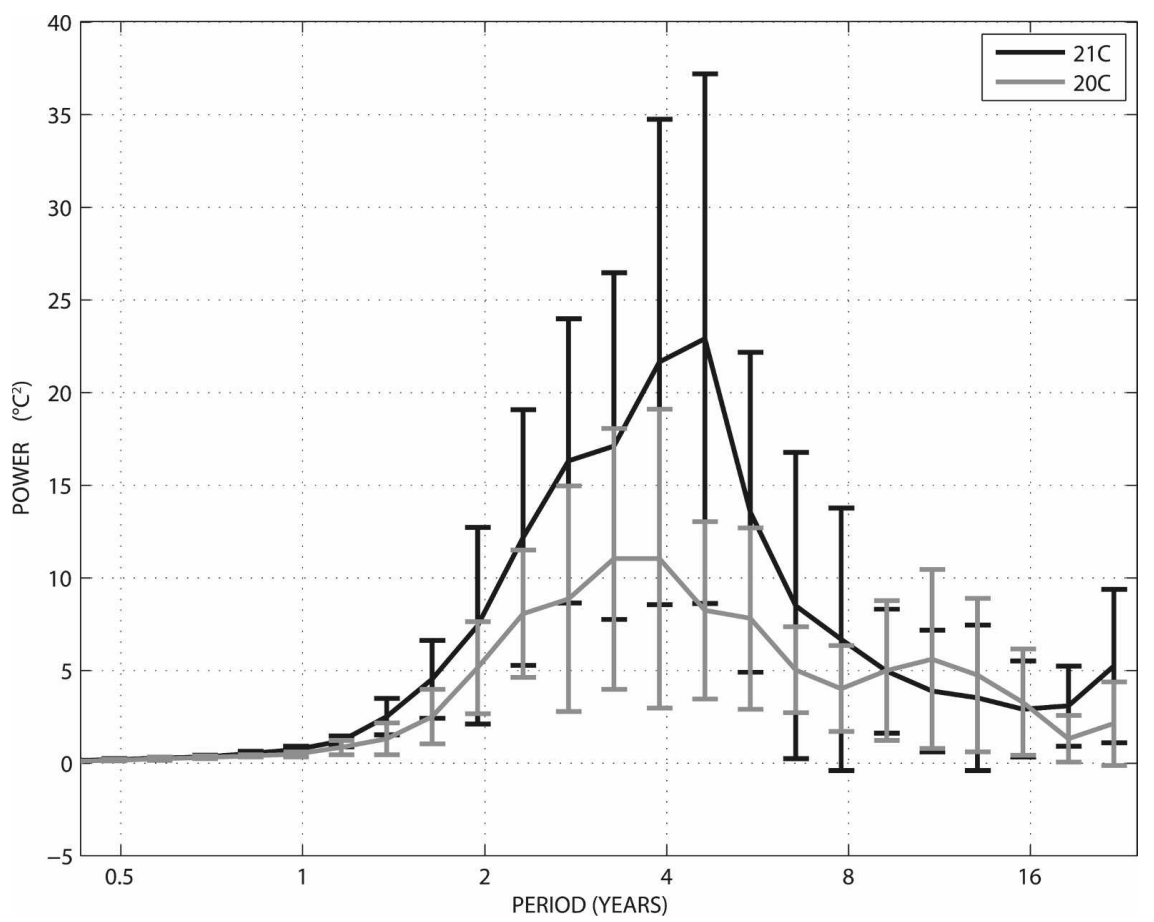

FIG. 15. Ensemble mean spectra $\left({ }^{\circ} \mathrm{C}^{2}\right)$ of Niño-3 SST anomalies. Spectra are computed from the last $30 \mathrm{yr}$ of the $21 \mathrm{C}$ experiments (after removing the linear trend) and eight nonoverlapping 30-yr chunks from the 20C control simulation. Bars indicate the 1 std dev range derived from the 8 individual members.

indicated by the large range given by the black bars in Fig. 15.

We next compute histograms of the simulated Niño-3 SST anomalies in order to study possible changes in distribution. The distribution becomes wider in the $21 \mathrm{C}$ integrations indicating an overall enhanced variability. Of particular interest are the changes at the tails, as they represent the extreme events. As can be seen from the time series (Fig. 14) both extreme warm and cold events become more frequent (Fig. 16a), with stronger changes in the warm extremes. This is reflected in the skewness which is slightly increased from $-0.03 \pm 0.21$ in $20 \mathrm{C}$ to $0.28 \pm 0.39$ in $21 \mathrm{C}$ (Table 1 ). The kurtosis changes from $2.60 \pm 0.31$ to $3.60 \pm 0.87$. The corresponding values for skewness and kurtosis in the observations are 0.75 and 4.13 (Table 1), respectively. Clearly, KCM's skewness and kurtosis are considerably lower than those obtained from observations, which indicates a too symmetric and not peaked enough distribution. Thus, it is debatable as to whether the changes in the higher moments of the distribution are reliable given the large biases.

Finally, in order to understand the reasons for the increase in ENSO variability we studied the response of the annual cycle in the eastern equatorial Pacific and also the changes in ocean-atmosphere feedbacks. As observed ENSO variability is phase locked to the annual cycle, changes in the annual cycle may impact ENSO amplitude and frequency (Chang et al. 1995; Liu 2002). The annual cycle response of Niño-3 SST shows a slight weakening (Fig. 16b). As the change is small and given the poor phase locking of ENSO to the annual cycle in the model, it seems unlikely that this change has any significant effect on KCM's ENSO response.

The four most important feedbacks for ENSO are the thermocline and zonal advective feedbacks, atmospheric response to SST, and thermal damping. Changes in these, which are largely controlled by changes in the mean state, impact ENSO variability (amplitude, period, and structure). Changes in the zonal advective feedback were not investigated in detail, but as the zonal asymmetry of the basic state did not change much (Fig. 11) and the westward propagation of equatorial SST anomalies remained similar (not shown), they appear to be of second-order importance. Changes in the other feedbacks were estimated by linear regression. As above, the analysis was performed on eight $30-y r$ chunks from $20 \mathrm{C}$ and $21 \mathrm{C}$ simulations. The thermocline feedback, estimated from the SST$20^{\circ} \mathrm{C}$ isotherm depth relation for the Niño-3 region, increases by $22 \%$ (Figs. 17a,b). The increased sensitiv- 
(a)

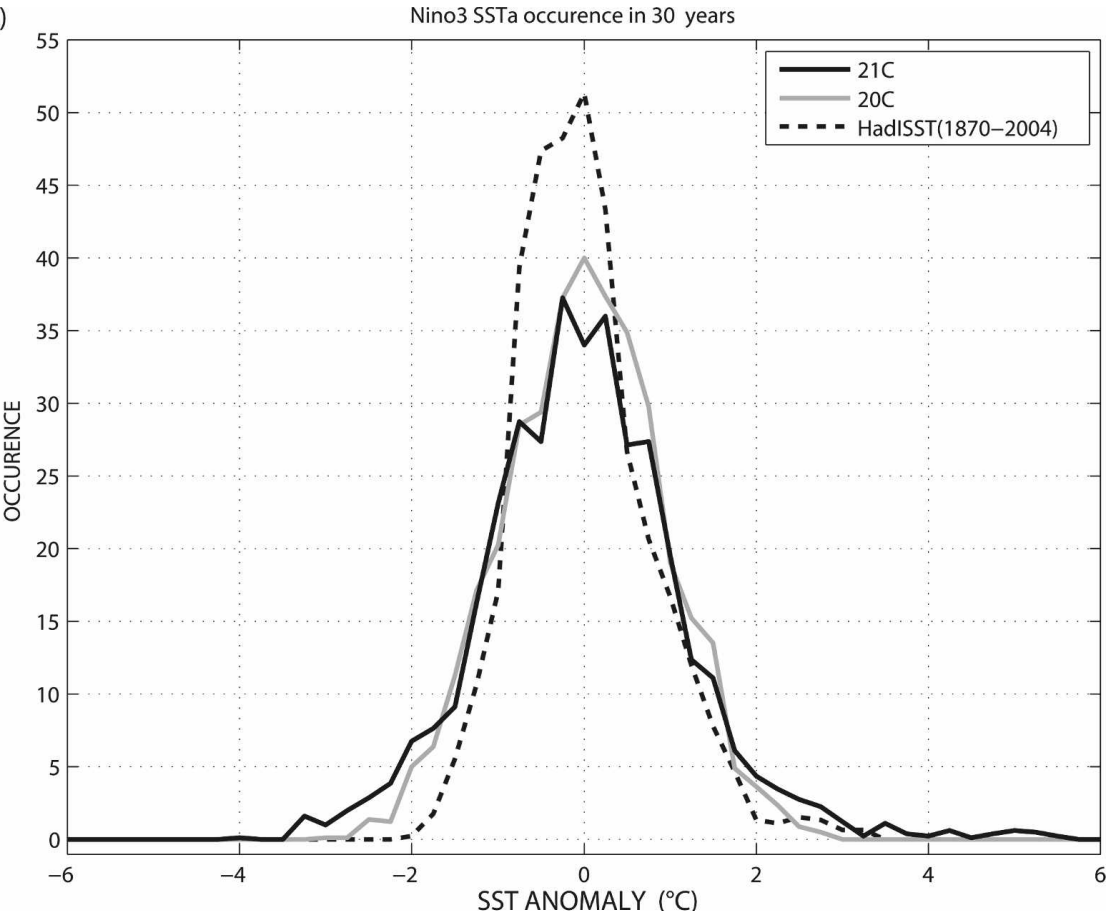

(b) Monthly mean of SST Nino3

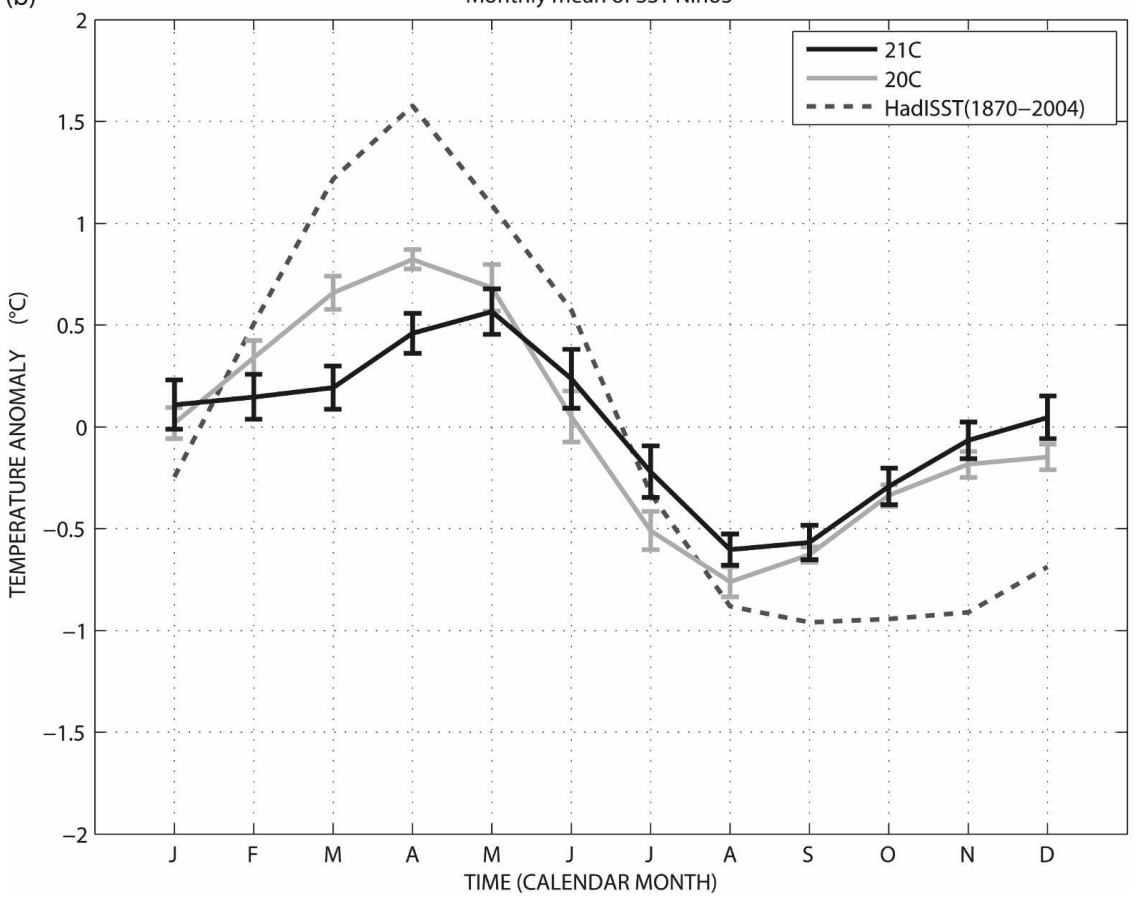

FIG. 16. (a) Histograms of monthly Niño-3 SST anomalies and (b) annual cycle (yearly mean removed) of Niño-3 SST $\left({ }^{\circ} \mathrm{C}\right.$ ). Periods of analysis of $20 \mathrm{C}$ (gray line) and $21 \mathrm{C}$ (black line) experiments are described in Fig. 15. Observations (dotted line; HadISST 1870-2004) are shown for comparison. 
(a) Nino3 $Z_{20}-$ Nino3 SST, 20C

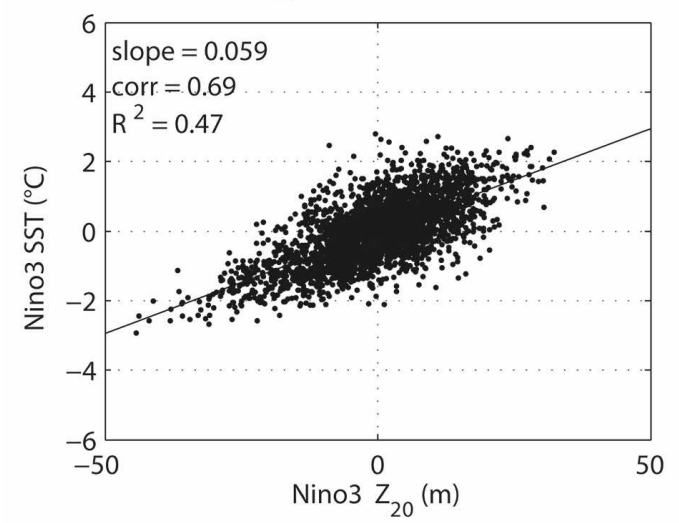

(c) Nino3 SST - Nino4 Ustrw, 20C

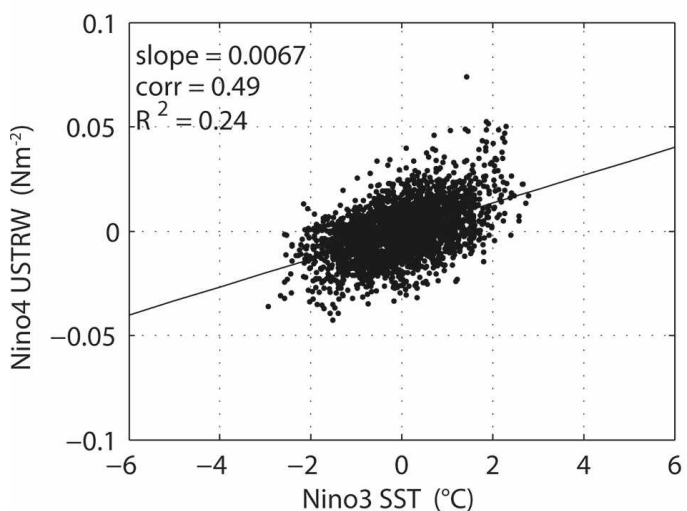

(b) Nino3 $Z_{20}-$ Nino3 SST, $21 \mathrm{C}$

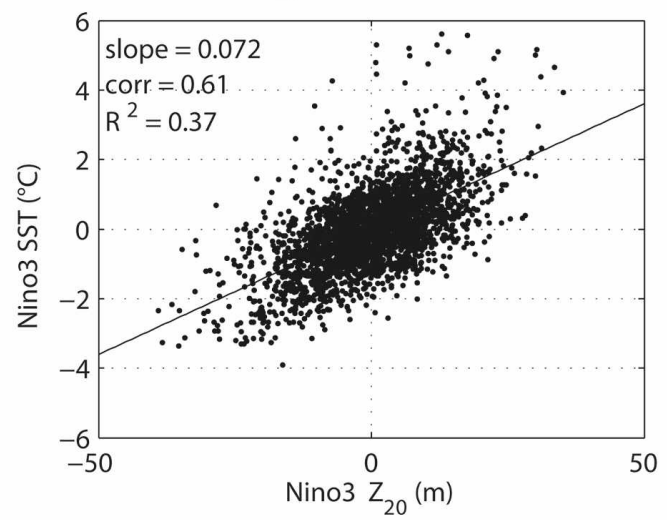

(d) Nino3 SST - Nino4 Ustrw, 21C

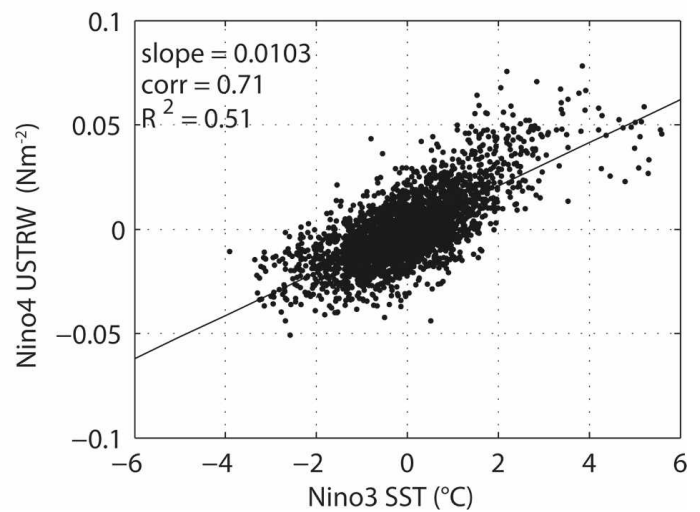

FIG. 17. Scatterplots and linear regression results for the feedback changes. (a), (b) Anomalies of Niño-3 $Z_{20}$ and Niño-3 SST; (c), (d) anomalies of Niño-3 SST and Niño-4 wind stresses. (a), (c) 20C; (b), (d) 21C experiments.

ity of SST to subsurface temperature anomalies is consistent with the sharper thermocline (Fig. 12a) and increased upwelling due to the strengthened trades (Fig. $12 \mathrm{c}$ ) in the $21 \mathrm{C}$ warming simulations. The atmospheric response to SST anomalies, estimated from the relation between Niño-4 zonal wind stress and Niño-3 SST, increases by $52 \%$ (Figs. $17 \mathrm{c}, \mathrm{d}$ ). The enhanced atmospheric sensitivity is likely due to the warmer atmospheric conditions, which supports an enhanced hydrological cycle. The thermal damping feedback, estimated from the net surface heat flux-SST relation for the Niño-3 region, becomes important in the $21 \mathrm{C}$ experiments (not shown). In the $20 \mathrm{C}$ control experiment the feedback is weak and could not be reliably estimated. Thus, the enhanced ENSO variability in the greenhouse experiments results from both the strengthening of the thermocline feedback and enhanced atmospheric sensitivity to SST.

\section{Summary and discussion}

In this paper we introduced the newly developed Kiel Climate Model (KCM) and described its performance in the tropical Pacific and response to global warming. Overall, the model's performance is reasonable, despite not using flux correction, and similar to that of other state-of-the-art global climate models, although we use relatively low resolution. However, as in most other global climate models, three main systematic errors are of major concern. First, northern midlatitude surface temperature is much too cold; second, the eastern tropical and subtropical oceans are much too warm; and third, the phase locking of ENSO to the annual cycle is not well captured. The latter indicates, together with the inability of the model to simulate a reasonable skewness of eastern equatorial Pacific SST anomalies, that KCM's ENSO dynamics are too linear. In spite of these deficiencies, the simulation of the annual cycle in the eastern equatorial Pacific and ENSO are quite good, with only small differences to observations. This is encouraging and we hope that KCM will become a useful tool to study climate variability, up to time scales of millennia, and predictability of the first and second kind, and to serve as kernel for the development of an earth system model. Much work, however, remains to 
reduce the biases described. This, however, is a longterm task. We have to find a trade-off between model resolution and systematic errors, because computer resources are still rather limited and enable only relatively short integrations at very high resolution. Physical parameterizations of unresolved processes can still be improved, and this is an attractive research area requiring deep insight into the underlying physics. We shall follow this latter route and increase of resolution is not our priority.

One of the major findings of this work is the intensification of ENSO in response to greenhouse warming, as simulated in a series of eight experiments with increasing $\mathrm{CO}_{2}$ concentration at $1 \% \mathrm{yr}^{-1}$ until doubling and then holding it constant. The ensemble mean standard deviation of Niño-3 SST anomalies increases by $26 \%$ in the $30 \mathrm{yr}$ after $\mathrm{CO}_{2}$ doubling, while there is a doubling in power at the dominant ENSO period of 4 yr. The increase in ENSO variability was driven by a $22 \%$ strengthening of the thermocline feedback and a $52 \%$ enhancement of atmospheric sensitivity to SST. The thermocline feedback enhancement results from a sharper thermocline and increased upwelling. The increase in atmospheric sensitivity may result from the warm atmospheric conditions, which drive an enhanced hydrological cycle. Although the ensemble mean changes in ENSO variability are large, there is quite some spread among ensemble members. This argues that climate change studies of ENSO should be probabilistic.

Timmermann et al. (1999) also found an enhancement of the thermocline feedback due to a sharpening of the thermocline. They used ECHAM4, the predecessor model of the ECHAM version used here, coupled to a completely different (isopycnal) ocean model. In contrast to Timmermann et al. (1999), the skewness in KCM changes in the opposite sense, such that extreme warm events, as opposed to extreme cold events, become more frequent. Several models do simulate enhanced interannual variability in response to global warming (van Oldenborgh et al. 2005; Guilyardi 2006), but there is still considerable spread among the different models. Since a number of feedbacks are involved in the ENSO response to global warming, the mean state in the tropical Pacific should be well simulated, as the large biases reduce confidence in the models. We do not know, for instance, as to whether the zonally symmetric response of the mean state in KCM affects the ENSO response. Furthermore, at this stage of analysis we also do not know whether the enhanced interannual variability is a transient phenomenon. The response time of the subsurface ocean is much longer than that of the surface ocean, which may lead to some additional warming at deeper levels, thereby counteracting the surface layer effects. Thus a much longer stabilization phase is needed to obtain an equilibrium response. Nevertheless, the real ocean may behave in a similar way, so that a transient increase in interannual variability is quite possible during this century, if greenhouse gas emissions are not strongly reduced.

Acknowledgments. We would like to thank the MaxPlanck-Institut für Meteorologie and LOCEANInstitut Pierre Simon Laplace for generously providing ECHAM5 and NEMO, respectively. We would like to thank M. Schneiert for providing a standalone NEMO simulation. Discussions with J. Jungclaus, M. Esch, L. Kornblueh, and S. Hagemann on ECHAM5; V. Gayler, S. Legutke, E. Maisonnave, and S. Valcke on OASIS3; and the DRAKKAR group, A. Biastoch, and S. Masson on NEMO were very helpful during the model development. We are grateful to the reviewers for the useful comments. We thank Frauke Nevoigt for the help in preparing the final figures. This work was supported by the European Union's projects ENSEMBLES (GOCE-CT-2003-505539) and DYNAMITE (Contract 003903). The model integrations were performed at the Deutsches Klimarechenzentrum and the Computer Centre at Kiel University.

\section{REFERENCES}

Achuta Rao, K., and K. R. Sperber, 2000: El Niño Southern Oscillation in coupled models. PCMDI Rep. 61, PCMDI, Lawrence Livermore National Laboratory, University of California, Livermore, CA, 46 pp.

- , and ——, 2006: ENSO simulation in coupled oceanatmosphere models: Are the current models better? Climate Dyn., 27, 1-15, doi:10.1007/s00382-006-0119-7.

Barnier, B., and Coauthors, 2006: Impact of partial steps and momentum advection schemes in a global ocean circulation model at eddy-permitting resolution. Ocean Dyn., 56, 543567.

Battisti, D. S., and A. C. Hirst, 1989: Interannual variability in a tropical atmosphere-ocean model: Influence of the basic state, ocean geometry, and nonlinearity. J. Atmos. Sci., 46, $1687-1712$.

Bjerknes, J., 1969: Atmospheric teleconnections from the equatorial Pacific. Mon. Wea. Rev., 97, 163-172.

Busalacchi, A. J., and J. J. O'Brien, 1981: Interannual variability of the equatorial Pacific in the 1960's. J. Geophys. Res., 86, 10 901-10 907.

Chang, P., L. Ji, B. Wang, and T. Li, 1995: Interactions between the seasonal cycle and El Niño-Southern Oscillation in an intermediate coupled ocean-atmosphere model. J. Atmos. Sci., 52, 2353-2372.

Collins, M., and The CMIP Modelling Groups, 2005: El Niño- or La Niña-like climate change? Climate Dyn., 24, 89-104, doi:10.1007/s00382-004-0478-x. 
Cubasch, U., and Coauthors, 2001: Projections of future climate change. Climate Change 2001: The Scientific Basis, J. T. Houghton et al., Eds., Cambridge University Press, 525-582.

Davey, M. K., and Coauthors, 2002: STOIC: A study of coupled model climatology and variability in tropical ocean regions. Climate Dyn., 18, 403-420.

Fedorov, A. V., and S. G. H. Philander, 2000: Is El Niño changing? Science, 288, 1997-2002.

— , and —, 2001: A stability analysis of tropical oceanatmosphere interactions: Bridging measurements and theory for El Niño. J. Climate, 14, 3086-3101.

Fichefet, T., and M. A. Morales Maqueda, 1997: Sensitivity of a global sea ice model to the treatment of ice thermodynamics and dynamics. J. Geophys. Res., 102, 12 609-12 646.

Gualdi, S., E. Guilyardi, A. Navarra, S. Masina, and P. Delecluse, 2003: The interannual variability in the tropical Indian Ocean as simulated by a CGCM. Climate Dyn., 10, 567-582.

Guilyardi, E., 2006: El Niño-mean state-seasonal cycle interactions in a multi-model ensemble. Climate Dyn., 26, 329-348.

—, P. Delecluse, S. Gualdi, and A. Navarra, 2003: Mechanisms for ENSO phase change in a coupled GCM. J. Climate, 16, 1141-1158.

— ocean-atmosphere GCMs: The dominant role of the atmospheric component. J. Climate, 17, 4623-4629.

Jin, F. F., 1997: An equatorial ocean recharge paradigm for ENSO. Part I: Conceptual model. J. Atmos. Sci., 54, 811-829.

Jochum, M., R. Murtugudde, R. Ferrari, and P. MalanotteRizzoli, 2005: The impact of horizontal resolution on the equatorial mixed layer heat budget in ocean general circulation models. J. Climate, 18, 841-851.

Kalnay, E., and Coauthors, 1996: The NCEP/NCAR 40-Year Reanalysis Project. Bull. Amer. Meteor. Soc., 77, 437-471.

Large, W. G., and S. G. Yeager, 2004: Diurnal to decadal global forcing for ocean and sea-ice models: The data sets and flux climatologies. NCAR Tech. Note NCAR/TN-460+STR, 111 pp. [Available online at http://www.cgd.ucar.edu/oce/pubs/ 04pubs_files/TN460.pdf.]

Latif, M., T. P. Barnett, M. A. Cane, M. Flugel, N. E. Graham, H. Von Storch, J. S. Xu, and S. E. Zebiak, 1994: A review of ENSO prediction studies. Climate Dyn., 9, 167-179.

— tercomparison Project. Climate Dyn., 18, 255-276.

Levitus, S., and Coauthors, 1998: World Ocean Data Base 1998. NOAA Atlas NESDIS 18, 346 pp.

Lin, J.-L., 2007: Interdecadal variability of ENSO in 21 IPCC AR4 coupled GCMs. Geophys. Res. Lett., 34, L12702, doi:10.1029/ 2006 GL028937.

Liu, Z., 2002: A simple model study of ENSO suppression by external periodic forcing. J. Climate, 15, 1088-1098.

Lohmann, K., and M. Latif, 2005: Tropical Pacific decadal variability and the subtropical-tropical cells. J. Climate, 18, 51635178.

Luo, J.-J., S. Masson, E. Roeckner, G. Madec, and T. Yamagata, 2005: Reducing climatology bias in an ocean-atmosphere CGCM with improved coupling physics. J. Climate, 18, 23442360.

Ma, C.-C., C. R. Mechoso, A. W. Robertson, and A. Arakawa, 1996: Peruvian stratus clouds and the tropical Pacific circu- lation: A coupled ocean-atmosphere GCM study. J. Climate, 9, 1635-1645.

Madec, G., 2008: NEMO ocean engine. Note du Pole de modélisation 27, Institut Pierre-Simon Laplace, 193 pp.

—, P. Delecluse, M. Imbard, and C. Lévy, 1998: OPA 8.1 Ocean General Circulation Model reference manual. Note du Pole de modélisation 11, Institut Pierre-Simon Laplace, 91 pp.

McPhaden, M. J., S. P. Hayes, L. J. Mangum, and J. M. Toole, 1990: Variability in the western equatorial Pacific Ocean during the 1986-87 El Niño/Southern Oscillation event. J. Phys. Oceanogr., 20, 190-208.

— and Coauthors, 1998: The tropical ocean global atmosphere observing system: A decade of progress. J. Geophys. Res., 103 (C7), 14 169-14 240.

Meehl, G. A., P. R. Gent, J. M. Arblaster, B. L. Otto-Bliesner, E. C. Brady, and A. Craig, 2001: Factors that affect the amplitude of El Niño in global coupled climate models. Climate Dyn., 17, 515-526.

Neelin, J. D., and Coauthors, 1992: Tropical air-sea interaction in general circulation models. Climate Dyn., 7, 73-104.

_ M. Latif, and F.-F. Jin, 1994: Dynamics of coupled oceanatmosphere models: The tropical problem. Annu. Rev. Fluid Mech., 26, 617-659.

— D. S. Battisti, A. C. Hirst, F.-F. Jin, Y. Wakata, T. Yamagata, and S. E. Zebiak, 1998: ENSO theory. J. Geophys. Res. 103 (C7), 14 261-14 290.

Philander, S. G. H., D. Gu, G. Lambert, T. Li, D. Halpern, N.-C. Lau, and R. C. Pacanowski, 1996: Why the ITCZ is mostly north of the equator. J. Climate, 9, 2958-2972.

Rayner, N. A., D. E. Parker, E. B. Horton, C. K. Folland, L. V. Alexander, D. P. Rowell, E. C. Kent, and A. Kaplan, 2003: Global analyses of sea surface temperature, sea ice, and night marine air temperature since the late nineteenth century. $J$. Geophys. Res., 108, 4407, doi:10.1029/2002JD002670.

Reynolds, R. W., and T. M. Smith, 1994: Improved global sea surface temperature analyses using optimum interpolation. $J$. Climate, 7, 929-948.

Roeckner, E., and Coauthors, 2003: The atmospheric general circulation model ECHAM5. Part I: Model description. Max Planck Institute for Meteorology Rep. 349, 127 pp. [Available from MPI for Meteorology, Bundesstr. 53, 20146 Hamburg, Germany.]

— horizontal and vertical resolution in the ECHAM5 atmosphere model. J. Climate, 19, 3771-3791.

Schopf, P. S., and M. J. Suarez, 1988: Vacillations in a coupled ocean-atmosphere model. J. Atmos. Sci., 45, 549-566.

Solomon, A., and D. Zhang, 2006: Pacific subtropical cell variability in coupled climate model simulations of the late 19th20th century. Ocean Modell., 15, 236-249, doi:10.1016/ j.ocemod.2006.03.007.

Solomon, S., D. Qin, M. Manning, Z. Chen, M. Marquis, K. B. Averyt, M. Tignor, and H. L. Miller, Eds., 2007: Climate Change 2007: The Physical Science Basis. Cambridge University Press, 996 pp.

Timmermann, A., J. Oberhuber, A. Bacher, M. Esch, M. Latif, and E. Roeckner, 1999: Increased El Niño frequency in a climate model forced by future greenhouse warming. Nature, 398, 694-697. 
Tompkins, A., 2002: A prognostic parameterization for the subgrid-scale variability of water vapor and clouds in large-scale models and its use to diagnose cloud cover. J. Atmos. Sci., 59, 1917-1942.

Valcke, S., Ed., 2006: OASIS3 user guide. PRISM Tech. Rep. 3, 64 pp. [Available online at http://www.prism.enes.org/ Publications/Reports/oasis3_UserGuide_T3.pdf.]

van Oldenborgh, G. J., S. Y. Philip, and M. Collins, 2005: El Niño in a changing climate: A multi-model study. Ocean Sci., 1, $81-95$.

Xie, S.-P., and P. A. Arkin, 1997: Global precipitation: A 17-year monthly analysis based on gauge observations, satellite estimates, and numerical model outputs. Bull. Amer. Meteor. Soc., 78, 2539-2558.

Zebiak, S. E., and M. A. Cane, 1987: A model El Niño-Southern Oscillation. Mon. Wea. Rev., 115, 2262-2278. 